Contract No. and Disclaimer:

This manuscript has been authored by Savannah River Nuclear Solutions, LLC under Contract No. DE-AC09-08SR22470 with the U.S. Department of Energy. The United States Government retains and the publisher, by accepting this article for publication, acknowledges that the United States Government retains a non-exclusive, paid-up, irrevocable, worldwide license to publish or reproduce the published form of this work, or allow others to do so, for United States Government purposes. 


\title{
RADIATION ECOLOGY ISSUES ASSOCIATED WITH MURINE RODENTS AND SHREWS IN THE CHERNOBYL EXCLUSION ZONE
}

\author{
Sergey P. Gaschak, Julia A. Maklyuk, Andrey M. Maksimenko, \\ Mikhail D. Bondarkov, ${ }^{*}$ G. Timothy Jannik ${ }^{\dagger}$ and Eduardo B. Farfán ${ }^{\dagger}$ \\ *hernobyl Center for Nuclear Safety, Radioactive Waste and Radioecology, International Radioecology \\ Laboratory, 07100, Slavutych, Ukraine \\ ${ }^{\dagger}$ Savannah River National Laboratory, Aiken, SC 29808, USA
}

\section{For reprints and correspondence contact:}

Eduardo B. Farfán, Ph.D.

Environmental Science and Biotechnology

Environmental Analysis Section

Savannah River National Laboratory

Savannah River Nuclear Solutions, LLC

773-42A, Room 236

Aiken, SC 29808

E-mail: Eduardo.Farfan@srnl.doe.gov

Phone: (803) 725-2257, Fax: (803) 725-7673

\section{Part of the Savannah River National Laboratory HPJ Special Issue}

October 2011 


\begin{abstract}
This article describes major studies performed by the Chernobyl Center's International Radioecology Laboratory (Slavutich, Ukraine) on radioecology of murine rodents and shrews inhabiting the Chernobyl Exclusion Zone. The article addresses the long-term (1986 - 2005) and seasonal dynamics of radioactive contamination of animals, and reviews interspecies differences in radionuclide accumulations and factors affecting the radionuclide accumulations. It is shown that bioavailability of radionuclides in the "soil-to-plant" chain and a trophic specialization of animals play key roles in determining their actual contamination levels. The total absorbed dose rates in small mammals significantly reduced during the years following the Chernobyl Nuclear Power Plant accident. In 1986, the absorbed dose rate reached $1.3-6.0 \mathrm{~Gy} \mathrm{hr}^{-1}$ in the central areas of the Chernobyl Exclusion Zone (the "Red Forest"). In 1988 and 1990, the total absorbed dose rates were 1.3 and $0.42 \mathrm{~Gy} \mathrm{hr}^{-1}$, respectively. In 1995, 2000, and 2005, according to the present study, the total absorbed dose rates rarely exceeded $0.00023,0.00018$, and $0.00015 \mathrm{~Gy}$ $\mathrm{hr}^{-1}$, respectively. Contributions of individual radiation sources into the total absorbed dose are described.
\end{abstract}

Key words: Chernobyl, mice, dose assessment, ${ }^{90} \mathrm{Sr},{ }^{137} \mathrm{Cs}$. 


\section{INTRODUCTION}

A comprehensive evaluation of radioecological consequences of the Chernobyl Nuclear Power Plant (ChNPP) accident in April 1986 presents a complex task that requires long-term observations; thereby, making the Chernobyl Exclusion Zone (ChEZ) a one-of-a-kind research site where various groups of species can be studied. Among all other species, small mammals, such as murine rodents and shrews, appear to be the most common objects of studies. They have been studied since the very first months after the ChNPP accident as a reference group; however, the primary focus of those studies was associated with biological effects. Meanwhile, the assessments of these effects only make sense relative to received doses, but, for a long time, the doses received by wild animals have not been addressed. Detailed studies on accumulation, distribution and excretion of radionuclides have been conducted for a long time, but primarily regarding agricultural and laboratory animals (Buldakov and Moskalev 1968; Aleksakhin 1982; Korneev and Sirotkin 1987; Moskalev 1989; Vandecasteele et al. 1989), and, therefore, they are not fully applicable for extrapolation to wild species. There has been very little applicable information available on wild animals inhabiting the ChEZ (Kozlo et al. 1998; Chesser et al. 2000, 2001; Gaychenko et al. 2001; Oleksyk et al. 2002; Ryabokon et al. 2005; Taskaev et al. 1990). In view of this, in 1998 - 2010, the International Radioecology Laboratory (IRL) performed a wide range of studies on accumulation and metabolism of radionuclides, as well as on dose rates, in wild murine rodents and shrews under the actual conditions of the ChEZ. These studies were either independent studies or were conducted as part of joint international projects associated with studies of radiation impact on the genetic system of wild rodents and their laboratory analogous species (Matson et al. 2000; Rodgers, Baker 2000; Baker et al. 2001; 
Rodgers et al. 2001; Oleksyk et al. 2002, 2004; Wiggins et al. 2002; Wickliffe et al. 2002). Detailed descriptions of ${ }^{90} \mathrm{Sr}$ and ${ }^{137} \mathrm{Cs}$ distributions and assessments of parameters affecting their excretion from bodies of wild rodents can be found in earlier publications (Baryakhtar et al. 2003; Maklyuk et al. 2006, 2007a). This article presents a review of other studies that have been either published earlier in Russian language journals only, or not published at all. These studies can be roughly divided into two groups dedicated to: (1) long-term dynamics of radioactive contamination of small mammals and evaluation of factors affecting this process (Maklyuk et al. 2007c) and (2) evaluation of dose structures and values for wild rodents and shrews of the ChEZ (Maklyuk et al. 2007b).

\section{MATERIALS AND METHODS}

Only a few studies conducted in the ChEZ have assessed patterns of long-term changes of radioactive contamination in murine rodents and shrews (Rozhdestvenskaya et al. 1990; Taskaev et al. 1990; Rozhdestvenskaya 1995, 1999; Voytovich, 2000; Ryabokon et al. 2005). However, these patterns were assessed for fairly short periods of time and for entirely different radiation conditions. All available information had to be integrated to cover the entire post-Chernobyl period, but heterogeneity of the available data presented a serious obstacle for doing this. The IRL and other literature data (Rozhdestvenskaya 1999; Taskaev et al. 1990; Gaychenko 1995; Voytovich 1998; Chesser et al. 2000; Gaychenko et al. 2001; Ryabokon et al. 2005) were obtained in various studies at various sites and they were represented by non-equivalent samplings which varied in composition and size. Those studies combined data on seventeen

species of small mammals. However, no data were available for any of these species that would 
make it sufficient to study them individually. In view of this, it was decided to combine all available data disregarding differences in individual species in seasonal and long-term trends. The justification for this simplification was based on the following earlier established facts: (1) amplitudes and directions of seasonal fluctuations of ${ }^{90} \mathrm{Sr}$ and ${ }^{137} \mathrm{Cs}$ concentrations in the bodies of animals inhabiting the same area had compatible patterns and (2) interspecies differences in ${ }^{90} \mathrm{Sr}$ and ${ }^{137} \mathrm{Cs}$ accumulations significantly overlapped the actual data variation for each of these species (Chesser et al. 2000; Baryakhtar et al. 2003). Nevertheless, the presence of interspecies differences in radionuclide accumulation was acknowledged and could be proven.

The data obtained in 37 locations of both the Ukrainian and Belorussian parts of the $\mathrm{ChEZ}$ is presented. According to IRL data (concerning the ${ }^{90} \mathrm{Sr}$ and ${ }^{137} \mathrm{Cs}$ inventories in the upper $0-30 \mathrm{~cm}$ soil layer, $\mathrm{kBq} / \mathrm{m}^{2}$ ) and other published data, the radioactive contamination of the areas where the animals were sampled varied significantly (as estimated for 1 January 1992). Specifically, for ${ }^{137} \mathrm{Cs}$ the range was $39.9-115,366 \mathrm{kBq} \mathrm{m}^{-2}$ and for ${ }^{90} \mathrm{Sr}$ the range was 10.9 $72,771 \mathrm{kBq} \mathrm{m}^{-2}$. When surface contamination data were not available, the 1992 aerial gamma survey data were used (obtained by the Institute of Radioecology of the Ukrainian Academy of Agricultural Sciences, Pripyat SPA STC). Considering that, typically, there was a logarithmically normal frequency of the values distribution, the geometric mean value of the entire set of values was used. All the contamination density values for the areas where the animals were captured were estimated for the dates they were captured.

For the IRL datasets, the ${ }^{137} \mathrm{Cs}$ content was measured using a Canberra-Packard $\gamma$ spectrometer with HP-Ge or NaI detectors. The ${ }^{90} \mathrm{Sr}$ content for most of the samples (including live animals) was measured without radiochemical pretreatment using a $\beta$-spectrometer with a thin-film scintillation plastic detector developed by the Institute of Nuclear Research of the 
National Academy of Ukraine, Kiev (Bondarkov et al. 2011). For rapid and simultaneous in vivo measurements of ${ }^{90} \mathrm{Sr}$ and ${ }^{137} \mathrm{Cs}$ content in field conditions, a specially designed gamma- and beta-spectrometric system was used (Bondarkov et al. 2011). The ${ }^{90} \mathrm{Sr}$ content in low activity samples and calibration standards were estimated using a radiochemical oxalate method based on the ${ }^{90} \mathrm{Y}$ daughter.

Since various authors presented data on radioactive contamination of animals as either concentrations of radionuclides in raw tissues (or the entire body) or in air dried tissues, these initial data were modified to be able to integrate the information. That is, the data for individual tissues was scaled up to account for entire body contamination and for the dried samples, the tissue shrinkage loss factors were considered. In addition, the literature data for the total ${ }^{134} \mathrm{Cs} /{ }^{137} \mathrm{Cs}$ activities were adjusted to show just the ${ }^{137} \mathrm{Cs}$ activity.

In view of this, the following major assumptions and approaches were applied:

1. The processes of radionuclides intake and excretion in the bodies of all animals reached a dynamic equilibrium.

2. Eqn (1) was used to calculate the average ${ }^{90} \mathrm{Sr}$ concentration $\left(A_{\text {Sr-body }}\right)$ in the body of the animals:

$$
A_{\text {Sr-body }}=p_{\text {skel }} \times\left(A_{\text {Sr-skel }} / k_{\text {skel }}\right) \times a,
$$

where: $p_{\text {skel }}=0.08$ representing a fraction of the skeleton raw mass in the total body mass of small mammals measured by the IRL (Bondarkov et al. 2003; Baryakhtar et al. 2003; Maklyuk et al. 2006) and described in Schmidt-Nielsen (1987); $A_{\text {Sr-skel }}$ is the ${ }^{90} \mathrm{Sr}$ concentration in the skeleton on a dry mass basis; $k_{\text {skel }}=1.76$ representing the skeleton shrinkage loss factor (taken from unpublished IRL data); $a=1 / 0.93$ representing the empirically obtained coefficient that reflected the total ${ }^{90} \mathrm{Sr}$ content in the entire body $\left(C_{\mathrm{Sr}-\text { body }}=100 \%\right)$ to the ${ }^{90} \mathrm{Sr}$ content in the 
skeleton ratio $\left(C_{\mathrm{Sr}-\mathrm{skel}}=93 \%\right)$ in a dynamic equilibrium (taken from the IRL data measured for small mammals) (Bondarkov et al. 2003; Baryakhtar et al. 2003; Maklyuk et al. 2006).

3. The IRL studies showed that the average ${ }^{137} \mathrm{Cs}$ concentration in the whole body of the animals was a factor of 0.714 of the average ${ }^{137} \mathrm{Cs}$ concentration measured in the muscle tissues (Bondarkov et al. 2003; Baryakhtar et al. 2003; Maklyuk et al. 2006).

4. According to IRL unpublished data, the muscle tissue shrinkage loss factor is 3.46 . However, the factor of 4.0 introduced in Chesser et al. (2000) was applied to transform the data for this study.

5. Changes in the ratio of ${ }^{134} \mathrm{Cs} /{ }^{137} \mathrm{Cs}$ concentrations complied with laws of their physical decay, while chemically these two isotopes behaved identically. The available long-term data (since 8 February 1988) made it possible to identify parameters for the equation to calculate the ${ }^{137} \mathrm{Cs}$ activity $\left(A_{\mathrm{Cs} 137}\right)$ based on the total activity of the two isotopes $\left(A_{\mathrm{Sum}}\right)$ as shown in eqn (2):

$$
A_{\mathrm{Cs}-137}=A_{\mathrm{Sum}} /\left(1+1 /\left(4.0769 \times \mathrm{e}^{0.0008 \mathrm{t}}\right)\right. \text {, }
$$

where $t$ was a difference between the date the animal was captured and the conditional date of 2 February 1988.

It is important to note the fundamental difference between the IRL and literature data. The IRL datasets present a population of data on individual species, while the literature data contained average data or their ranges (and some publications did not indicate the animals sampling size). Therefore, the periods of 1986 - 1994 (literature data only) and 1995 - 2005 (IRL data included) were studied separately. 


\section{RESULTS}

\section{Long-term dynamics of radionuclide content in murine rodents and shrews of the ChEZ}

Since the initial data were obtained in a very large number of areas represented by varied sampling compositions and sizes, it was decided that (instead of directly using the measured radionuclide activity) the radionuclide transfer coefficient $\left(T_{a g},\left(\mathrm{kBq} \mathrm{kg}^{-1}\right) /\left(\mathrm{kBq} \mathrm{m}^{-2}\right)=\mathrm{m}^{2} \mathrm{~kg}^{-1}\right)$ in the soil-to-animal chain would be more a more appropriate parameter to be used in the analysis of long-term dynamics. Table 1 contains the results of this long-term dynamics analysis for the ${ }^{90} \mathrm{Sr}$ and ${ }^{137} \mathrm{Cs} T_{a g}$ factors.

During the first year or so following the ChNPP accident, the animals experienced a significant decrease in both the total content of all accumulated radionuclides and the ${ }^{137} \mathrm{Cs}$ content in particular. According to Rozhdestvenskaya et al. (1990) and Rozhdestvenskaya (1999), this decrease was due to the decay of the short-lived radionuclides and transport of the radioactive fallout from a more accessible location on the surface of the soil and plants to less accessible locations in upper soil layers. Specifically, the ${ }^{137} \mathrm{Cs} \mathrm{T}_{\mathrm{ag}}$ factor for bank voles (Myodes glareolus) decreased by a factor of 1.98 in 1987 and by a factor of 3.38 in 1988 (Rozhdestvenskaya 1999). In subsequent years (1988 to 1990), the ${ }^{134} \mathrm{Cs}+{ }^{137} \mathrm{Cs}$ content in all murine rodents increased for a short time. An unequivocal explanation of this is not found in the literature (Rozhdestvenskaya et al. 1990; Rozhdestvenskaya 1995, 1999; Ryabokon et al. 2005). Possibly, this phenomenon resulted from (1) the breakdown of fuel particles in the ChNPP fallout that increased the bioavailability of the cesium isotopes and (2) the environmental transport of the major radionuclides in the soil down towards the root layer. 
The literature data showed that, by mid-1990's, murine rodents experienced another significant decrease in their radioactive contamination. By 1992, bank voles experienced a decrease in the ${ }^{137} \mathrm{Cs} T_{a g}$ value by a factor of 6.9, in comparison with 1986 (Rozhdestvenskaya 1999) and, by mid-1990's, all murine rodents experienced a decrease in the ${ }^{137} \mathrm{Cs} T_{a g}$ value by two orders of magnitude (Table 1 and Ryabokon et al. 2005). The time of that event coincided with the time when the ${ }^{137} \mathrm{Cs}$ bioavailability in the soil-to-plant chain decreased due to a gradual binding of ${ }^{137} \mathrm{Cs}$ by the soil components (Ivanov and Kashparov 2003). This phenomenon can be considered to be the primary reason for the decrease in the animals' contamination. It is important to note that in Ivanov (2001) it was shown that the decrease of the ${ }^{137} \mathrm{Cs} T_{a g}$ values during this time period for the soil-to-plant chain was by an order of magnitude lower than the decrease observed in the soil-to-animal chain (Table 1), which signifies a significant reduction of ${ }^{137} \mathrm{Cs}$ intake by the animals in the "non-nutritional" pathways (e.g., soil ingestion).

Since there were very few literature data available on ${ }^{90} \mathrm{Sr}$ content in bodies of small mammals for the years 1986 to 1995 , it is assumed that most of the trends observed for ${ }^{137} \mathrm{Cs}$ would also be true for ${ }^{90} \mathrm{Sr}$. Specifically, by mid-1990's, due to a decrease in the ${ }^{90} \mathrm{Sr}$ bioavailability, the average ${ }^{90} \mathrm{Sr}$ contamination of animals significantly decreased (Table 1).

In general, during the period of 1986 to 1995 , the average ${ }^{90} \mathrm{Sr}$ and ${ }^{137} \mathrm{Cs}$ concentrations in bodies of small mammals decreased by factors of tens and hundreds primarily due to a decrease in bioavailability of these radionuclides. During that period of time, the average ${ }^{137} \mathrm{Cs} T_{a g}$ values decreased by a factor of 10 and the average ${ }^{90} \mathrm{Sr} T_{a g}$ values decreased by a factor of 30 , with ${ }^{137} \mathrm{Cs}$ and ${ }^{90} \mathrm{Sr}$ radioactive decay contributing only about a $1.28-1.29$ fold decrease of their initial average activities. 
In 1998 to 2005 , the ${ }^{137} \mathrm{Cs} T_{a g}$ value in the soil-to-animal chain did not change in principle, but underwent significant seasonal and long-lasting (several years long) fluctuations. The average ${ }^{90} \mathrm{Sr} T_{a g}$ value during the period of 1996 to 2000 increased by more than an order of magnitude (Table 1). Basically, this trend followed the trend of the ${ }^{90} \mathrm{Sr}$ bioavailability increase in the soil-to-plant chain (Ivanov 2001). Kashparov et al. (1999) explained this trend by a continuing destruction of the fallout fuel particles in the soil.

The significant variation shown in Table 1 in the average $T_{a g}$ values during the last few years of the study period (2000 to 2005) gave grounds to assess such factors as seasonal changes in radionuclide intake with food, presence of geographically dependent differences in radionuclide bioavailability, and trophic specialization of individual species. For example, in relatively small areas of the ChEZ with different soil and vegetation conditions (2002 data), the differences in the ${ }^{90} \mathrm{Sr}$ and ${ }^{137} \mathrm{Cs} T_{a g}$ values for bank voles reached factors between $1.2-4.8$ and $9.4-13.5$, respectively. In three areas with similar initial physical-chemical properties of the fallout located along the Western plume, the highest ${ }^{137} \mathrm{Cs} T_{a g}$ values were recorded for animals in wet conditions and peat soils and the highest ${ }^{90} \mathrm{Sr} T_{a g}$ values were recorded for animals in depleted sandy soils as shown in Table 2. However, in those areas where, due to the physicalchemical characteristics and moisture content of the soil, the destruction of the fallout fuel particles occurred more rapidly (Kashparov et al. 1999), the $T_{a g}$ values for both ${ }^{90} \mathrm{Sr}$ and ${ }^{137} \mathrm{Cs}$ appeared to be even higher (sod, sandy damp soils).

Another important factor affecting contamination of bodies of animals is related to their species-specific biology, metabolism, and locations in the trophic chains, which was repeatedly noted in publications addressing non-Chernobyl radiation conditions (Kaye and Dunaway 1962; Ilyenko 1974; Starichenko and Lubashevsky 1998) and in publications of the last decade on 
Chernobyl topics (Taskaev et al. 1990; Rozhdestvenskaya 1995; Suschenya et al. 1995; Baryakhtar et al. 2003). However, assessments of the capabilities of different species to accumulate radionuclides frequently vary from researcher to researcher mainly because the local and seasonal feeding patterns play additional important roles in these capabilities.

If, however, the data for only one area (by year) is considered separately, the differences in radionuclide accumulation between species should remain relatively constant. For example, the differences among all studied species in the "Glubokoe Lake" site (one of the areas of the ChEZ) in 1995 were not statistically significant (Fig. 1) although the ${ }^{137} \mathrm{Cs} T_{a g}$ values for bank voles were higher than those for other species. The 1998 sampling data demonstrated significant differences among all species in the following decreasing order: bank voles $>$ wood mice $($ Sylvaemus flavicollis $)>$ common shrews $($ Sorex araneus $)>$ short tailed voles (Microtus sp. $)>$ striped field mice (Apodemus agrarius) $(\mathrm{p}<0.05)$. According to the 2000 data, this sequence remained, however, only bank voles were characterized by the statistically valid highest values $(\mathrm{p}<0.05)$ (Fig. 1).

As shown in Fig. 2 for the "Red Forest" site of the ChEZ, during 1997 bank voles had the highest ${ }^{137} \mathrm{Cs} T_{a g}$ values and wood mice had the lowest values $(\mathrm{p}<0.05)$. In 2001 , the general decreasing order of the species did not change, but the absolute ${ }^{137} \mathrm{Cs} T_{a g}$ values went down for all species, with differences among most species being significant $(\mathrm{p}<0.05)$. In 2002, bank voles still had the highest ${ }^{137} \mathrm{Cs} T_{a g}$ values $(\mathrm{p}<0.05)$, however, common shrews switched from the more contaminated to the less contaminated group $(\mathrm{p}<0.05)$.

Therefore, among the analyzed species, bank voles were found to have the highest ${ }^{137} \mathrm{Cs}$ $T_{a g}$ values $(\mathrm{p}<0.05)$ more frequently than other species, while striped field mice were found to have the lowest ${ }^{137} \mathrm{Cs} T_{a g}$ values. Relative values for other species varied from area to area and as 
a function of time within one area. For example, in the "Lake Glubokoe" site, wood mice were found to be among the more contaminated species, but were relatively less contaminated in the "Red Forest" site. The common shrews were found to experience the opposite trend.

Unfortunately, it was not possible to perform a similar analysis for ${ }^{90} \mathrm{Sr}$ contamination because there was a smaller amount of the initial data available. Therefore, under this study, data for several years for individual areas with fairly large sampling sizes were combined (Table 3).

According to the existing data, the maximum ${ }^{90} \mathrm{Sr} T_{a g}$ values were found to be the most characteristic of common shrews and short tailed voles. Lower $T_{a g}$ values were found to be more characteristic of striped field mice, which also had the lowest ${ }^{137} \mathrm{Cs} T_{a g}$ values. The ${ }^{90} \mathrm{Sr} T_{a g}$ values for bank voles were about at the median values, while the wood mice values were varied, which might have been dictated by the available food supply in the specific area.

Since patterns of the radionuclide accumulation by a specific species depend on the diet of this species at a certain period of time in a certain area, they are bound to be directly impacted by the actual status of the local food supply. In addition, this impact may be so significant that the descending order of the animals regarding the radionuclide accumulation may drastically change. Theoretically, radionuclide composition and content in the species' diet can potentially change during one summer season. Therefore, comparison of data for consecutive and relatively short periods of time can demonstrate patterns of these changes. Such analysis was performed for bank voles inhabiting two areas: (1) "Red Forest" and (2) Novoshepelichy (NSHP) Forestry.

For the "Red Forest" site, all available data were combined for the period of $1997-2003$, which resulted in a fairly significant dispersion of values but showed that, from May to July, the ${ }^{137} \mathrm{Cs}$ accumulation indices increased by an order of magnitude and then remained approximately the same until September (Fig. 3). This pattern was observed for all age groups, which was a 
fairly important observation. Since the age structure of the population (and, consequently, the age structure of the sampling group) changes throughout summer because the fraction of young species increases and young animals a priori have a more intense metabolism, the average $T_{a g}$ values could have been expected to increase for the entire sampling group in the second half of summer. The existing data indicate a single type seasonal trend for all age groups and a tendency for young animals to have higher ${ }^{137} \mathrm{Cs} T_{a g}$ values. However, against the factors associated with long-term changes in the ${ }^{137} \mathrm{Cs}$ bioavailability, the anticipated differences between age groups were not statistically confirmed due to a lack of data for older age groups.

In the NSHP Forestry the study was conducted during 35 days in the summer of 2005 under a joint project on dose rate assessments for small mammals (Beresford et al. 2008). From this study a fairly large sampling set $\left(108\right.$ species, $263{ }^{90} \mathrm{Sr}$ and ${ }^{137} \mathrm{Cs}$ measurements including multiple captures) was obtained from the area of only 1 hectare. The data variation in this sampling set appeared to be significantly lower than the variation of multiannual data for the "Red Forest" area. However, the pattern of ${ }^{90} \mathrm{Sr}$ and ${ }^{137} \mathrm{Cs} T_{a g}$ variations during the entire period of the measurements was approximately the same as for the multiannual July and August measurements periods in the "Red Forest" site. The ${ }^{90} \mathrm{Sr}$ accumulation values were found to be $10-100 \%$ higher in small individuals (up to 21 grams) than in larger ones, while, on the contrary, the ${ }^{137} \mathrm{Cs} T_{a g}$ values were found to be $20-60 \%$ lower in small individuals (Table 4). Therefore, these studies confirmed that the radionuclides accumulation depended on the age of the animals.

It should also be noted that, among other things, a significant data variation in one sampling group could have resulted from a high metabolism in bodies of small mammals. Experiments with wild and laboratory small size $(15-50 \mathrm{~g})$ rodents showed that the ${ }^{90} \mathrm{Sr}$ and 
${ }^{137} \mathrm{Cs}$ excretion from their bodies occurred with half-lives of about $10-50$ days and $1.1-4.4$ days, respectively (Table 5) and they reached $90 \%$ of the dynamic equilibrium with the chronic intake on 33 - 166 days and on 5 - 15 days for ${ }^{90} \mathrm{Sr}$ and ${ }^{137} \mathrm{Cs}$, respectively.

Using the parameters shown in Table 5, the radionuclide intake is described with the second order equation provided in eqn (3):

$$
C_{t}=C_{0}\left[a_{1} e^{-\frac{0.693 t}{T_{1}}}+a_{2}\right]
$$

where $C_{t}$ is the radionuclide content in the body of the animal at $t$ days from the start of the experiment; $C_{0}$ is the initial radionuclide content; $a_{1}$ and $a_{2}$ are the excreted and not excreted fractions of the radionuclide; $T_{l}$ is the effective period of half-life of the excreted fraction of the radionuclide.

With these parameters, any change in the radionuclide intake with the diet can rapidly and significantly affect the total radionuclide content in the body, neutralizing the effect of sex, age, and species specific differences in the analysis of the generalized heterogeneous sampling group. The patterns of radionuclide accumulation that were studied the most thoroughly were for the bank voles, which is one of the most common species in the ChEZ. The patterns, to a large extent, can be directly applied to many other species of rodents and shrews. However, some special features of selected species, such as hibernation of dormice or hyperactivity of shrews, may affect or modify these patterns, thereby requiring their additional studies.

Therefore, the review of the literature and the IRL data on the ${ }^{90} \mathrm{Sr}$ and ${ }^{137} \mathrm{Cs}$ content in small mammals of the ChEZ in 1986 - 2005 showed that the average content of these radionuclides varied due to the following processes: radionuclide decay, change of radionuclides bioavailability in the soil-to-plant chain and a decrease in the role of the "non-nutritional" path of 
the radionuclide intake, i.e., when animals incidentally swallowed soil while eating or grooming. The fluctuations in the radioactive contamination of small mammals observed during the last few years are related to ongoing changes in the radionuclides bioavailability, seasonal and geographical changes of the food supply, as well as physiological differences of the sampled individuals. At the same time it is safe to say that the radionuclide transfer coefficients indicating the radionuclide transfer from the soil to the bodies of the animals have relatively stabilized, making it possible to assume that the future long-term dynamics of radionuclide content in these animals will, on the average, reflect the dynamics of the ${ }^{90} \mathrm{Sr}$ and ${ }^{137} \mathrm{Cs}$ decay, with, however, significant seasonal, annual, and geographical variations.

\section{Dose rate assessments for murine rodents and shrews}

Dose rate estimates are the key information needed for assessments of radiobiological effects. Under laboratory conditions, dose rates and other parameters can be regulated and measured. However, while working with animals in actual natural conditions, researchers encounter heterogeneity, uncertainty, and inability to control the majority of the parameters. These challenges are associated with a simultaneous impact of several types of ionizing radiation on the body, simultaneous external and internal radiation, uneven distribution of sources of ionizing radiation in the ecosystem, heterogeneity of non-radiation related environmental conditions, species specific physiology, trophic specialization, location specific behavior, and many other factors (Tikhomirov 1971). The similarity principle approach (when radioecological assessments for one species are transferred to other species) could cause an incorrect interpretation of the obtained results and over- or underestimation of the radiation impact. To avoid this, dose rate assessments for various species of wild animals are required. 
Such studies were performed in the ChEZ, but more or less detailed descriptions of the dose rate calculations and/or assessments methods were only provided in a small number of publications (Taskaev et al. 1990; Chesser et al. 2000; Baryakhtar et al. 2003; Ryabokon et al. 2005; Beresford et al. 2008). In most papers, the authors limited themselves by only stating the dose rate values. However, all these studies are of a great interest because they were conducted at various phases of the post-Chernobyl period and, in spite of a significant difference of the methodological approaches, they made it possible to gain an insight into both changes in the dose rates and changes of roles of various radiation sources. On the other hand, the problems associated with dose rate assessments for wild small mammals still await their solutions. Specifically, scientists do not know how dose rates differ for animals of various species that inhabit the same area, how biotopic conditions affect the doses, how the animals' behavior affects the dose rate, etc. It is also important to take into account the fact that radioecological conditions keep changing.

To gain understanding on some of the problems, an assessment of the dose rates for small mammals inhabiting several areas of the ChEZ with various radioecological conditions was performed (Maklyuk et al. 2007c). The baseline for this study was obtained in 2005 under another research project that was also focused on dose rates assessments but using thermoluminescent dosimetry (TLD) and the ERICA Tool software package (Beresford et al. 2008).

In Maklyuk et al. (2007c), dose rate values and structures were estimated for the following four species: bank voles, wood mice, short tailed voles, and common shrews. For this purpose, during 35 days of the July-August period, a series of captures of the animals were performed for in vivo ${ }^{90} \mathrm{Sr}$ and ${ }^{137} \mathrm{Cs}$ measurements in the whole body. After the measurements were complete, all the animals, with the exception of the shrews, were labeled and set free. In 
total, (taking into account the animals that were repeatedly captured and re-measured) 652 measurements were made to deteremine ${ }^{90} \mathrm{Sr}$ and ${ }^{137} \mathrm{Cs}$ concentrations. To characterize the radiation conditions, the gamma equivalent dose rate and the beta flux were measured in 100 locations at each site at $5 \mathrm{~cm}$ above the soil surface level. In addition, the soil from the $0-20 \mathrm{~cm}$ upper layer was sampled to evaluate its isotopic composition at 20 locations for each site. Since the ${ }^{40} \mathrm{~K},{ }^{60} \mathrm{Co},{ }^{134} \mathrm{Cs},{ }^{154} \mathrm{Eu},{ }^{238,239,240} \mathrm{Pu}$, and ${ }^{241} \mathrm{Am}$ content in the soil was by $2-3$ orders of magnitude lower than the ${ }^{90} \mathrm{Sr}$ and ${ }^{137} \mathrm{Cs}$ content and also since the ${ }^{60} \mathrm{Co},{ }^{154} \mathrm{Eu},{ }^{238,239,240} \mathrm{Pu}$ and ${ }^{241}$ Am bioavailability was low, only the ${ }^{90} \mathrm{Sr}$ and ${ }^{137} \mathrm{Cs}$ content was taken into account for the dose rate calculations. The dose rate calculations were based on the geometric mean values that characterized the radiation conditions of the three areas that were sampled for this study (Table 6) and on the measured concentrations of the animals living in those areas (Table 7).

To calculate the absorbed dose from the external radiation sources, the previously obtained gamma equivalent dose rates and beta flux measurements at the $5 \mathrm{~cm}$ above the soil surface level were used. It was assumed that, at this height, the gamma dose rate and the absorbed dose would correspond to the absorbed dose rate in the body of the animals. To assess the dose from the external beta radiation, a simplified beta-flux based calculation method was used. The external gamma and beta doses $\left(D_{\gamma}\right.$ and $\left.D_{\beta}\right)$ were calculated using eqns (4) and (5), respectively:

$$
\begin{aligned}
& D_{\gamma}=M_{1} \times T_{1}+M_{2} \times T_{2}, \\
& D_{\beta}=G\left(B_{1} \times T_{1}+B_{2} \times T_{2}\right),
\end{aligned}
$$

where: $M_{1}$ is the equivalent dose rate above the soil surface $\left(\mu \mathrm{Gy} \mathrm{hr}{ }^{-1}\right) ; M_{2}$ is the equivalent dose rate in a burrow $\left(\mu \mathrm{Gy} \mathrm{hr}{ }^{-1}\right) ; T_{1}$ is the duration of the animal's stay on the soil surface during a 24hour period (hours); $T_{2}$ is the duration of the animal's occupancy in the burrow during a 24-hour 
period (hours); $G$ is the adjusted coefficient being equal to $2.7 \times 10^{-10} \mathrm{~Gy} \mathrm{~cm}^{2}$ per particles (Osanov 1990); $B_{1}$ is the beta flux density on the soil surface (particle $\mathrm{cm}^{-2} \mathrm{~min}^{-1}$ ); and $B_{2}$ is the beta flux density in the burrow, (particle $\mathrm{cm}^{-2} \mathrm{~min}^{-1}$ ).

It was taken into consideration that the small mammals spend some time on the soil surface or in the upper layer of the ground litter and the remaining time in their burrows. Since there was no direct assessments of this time distribution, the following assumed values were used to estimate ratios for the time spent on the soil surface and the ground litter versus the time spent in the burrows $\left(T_{1} / T_{2}\right)$ : for bank voles $0.3 / 0.7$; for wood mice $0.35 / 0.65$; for short tailed voles 0.5/0.5; for common shrews $0.65 / 0.35$. Since there was no direct measurements of dose rate on the soil surface or in the borrows ( $20 \mathrm{~cm}$ below the soil surface) it was assumed that their ratio is equal to 2 for the gamma-radiation and 2.5 for the beta-radiation.

The adjusted coefficient $\mathrm{G}\left(2.7 \times 10^{-10} \mathrm{~Gy}_{\mathrm{cm}}^{2}\right.$ per particles was taken from Osanov (1990) as the most probable coefficient for the skin layer of $0.05-1.0 \mathrm{~mm}$ thick for the isotropic external beta flux with the maximum energy of $0.4-2.4 \mathrm{MeV}$. The major beta-emitters, such as ${ }^{90} \mathrm{Sr},{ }^{90} \mathrm{Y}$, and ${ }^{137} \mathrm{Cs}$, are located within this range (Table 8)

Eqn (6) taken from Moiseev and Ivanov (1990) was applied to calculate the absorbed dose from the gamma emitting radionuclide incorporated in the tissues of the animal:

$$
D=q g \rho K_{\gamma},
$$

where: $q$ is the concentration of the radionuclide $\left(\mathrm{Bq} \mathrm{g}^{-1}\right) ; g$ is the average geometric factor $(\mathrm{m})$; $\rho$ is the tissue density $\left(\mathrm{kg} \mathrm{m}^{-3}\right) ; K_{\gamma}$ is the kerma constant of the radionuclide $\left(2.1 \times 10^{-13} \mathrm{~Gy} \mathrm{~cm}^{2}\right.$ $\left.\mathrm{s}^{-1} \mathrm{~Bq}^{-1}\right)$. For simplification, the geometric shape of the animals was assumed to be a simple cylinder with a certain geometric factor $g$. 
The gamma-radiation contribution into the total absorbed dose from the incorporated radionuclides depends on the tissue size and the ratio of the gamma rays and beta particles per disintegration, and it can range from a few fractions to several dozens of percent (Kozlov 1987). Usually, the gamma-radiation dose can be disregarded if the relationship given in eqn (7) is true:

$$
\frac{E_{\text {aver }}}{G_{\gamma}} \geq 4.7 \times 10^{-4} \mathrm{~g}
$$

where $E_{\text {aver }}$ is the average beta-spectrum energy $(\mathrm{MeV}) ; G_{\gamma}$ is the gamma-constant of the radionuclide $\left(\mathrm{P} \mathrm{cm}^{2} \mathrm{mCi}^{-1} \mathrm{hr}^{-1}\right) ; g=4 \pi R$ is the average geometric factor $(R$-radius sphere $)(\mathrm{m})$. The calculation shows that for ${ }^{137} \mathrm{Cs}\left(E_{\text {aver }}=0.18 \mathrm{MeV} ; G_{\gamma}=3.24 \mathrm{P} \mathrm{cm}^{2} \mathrm{mCi}^{-1} \mathrm{hr}^{-1}\right)$, the eqn (7) condition will be true for the sphere with the radius shorter than $0.12-0.13 \mathrm{~m}$ (i.e., the size range for small mammals).

Nevertheless, the contribution of the gamma rays can be estimated using the equation proposed for the non-absorbing cylinder with an evenly distributed activity (Kozlov 1987) as provided in eqn (8):

$$
P=2 \pi A_{\nu} Y\left[r \operatorname{arctg} \frac{h}{r}+r \operatorname{arctg} \frac{H-h}{r}-h \ln \frac{h}{\sqrt{h^{2}+r^{2}}}-(H-h) \ln \frac{H-h}{\sqrt{(H-h)^{2}+r^{2}}}\right],
$$

where $P$ is the absorbed dose rate $\left(\mathrm{Gy} \mathrm{s}^{-1}\right) ; A_{v}$ is the volume activity $\left(\mathrm{Bq} \mathrm{m}^{-3}\right) ; Y$ is the constant kerma of the radionuclide $\left(\mathrm{Gy} \mathrm{m}^{2} \mathrm{~s}^{-1} \mathrm{~Bq}^{-1}\right) ; H$ is the full height $(\mathrm{m}) ; h$ is the height along the axis of the cylinder $(\mathrm{m}) ; r$ is the radius of the base of the cylinder $(\mathrm{m})$.

If it is assumed that the geometry of a murine rodent is a $10-15 \mathrm{~cm}$ high cylinder with a $1.5-2 \mathrm{~cm}$ radius, the absorbed dose ratio $\mathrm{D}_{\beta} / \mathrm{D}_{\gamma}$ will be $4-6$ in the center and $8-12$ on the surface. Such an insignificant addition of the ${ }^{137} \mathrm{Cs}$ gamma-radiation energy can be considered if it adds $0.04 \mathrm{MeV}$ to the average energy of beta-decay $(0.18 \mathrm{MeV})$ and it is assumed that the 
effective energy of one disintegration is equal to $0.22 \mathrm{MeV}$. This contribution is even smaller for smaller animals.

The calculations of the absorbed beta-radiation dose from the incorporated radionuclides are straightforward only if the linear dimensions of the object $L$ do not exceed the range of the beta-particle in the substance. For biologically important radionuclides $\left({ }^{40} \mathrm{~K},{ }^{90} \mathrm{Sr},{ }^{90} \mathrm{Y},{ }^{137} \mathrm{Cs}\right)$, this range is from 1 to $10 \mathrm{~mm}$ (Table 8). In this case, the calculations of the absorbed dose are conducted as those for an infinitely extended source as provided in eqn (9):

$$
D_{\beta}=E_{\text {aveg }} q k T
$$

where $D$ is the absorbed dose $\left(\mathrm{Gy} \mathrm{d}^{-1}\right) ; E_{\text {aveg }}$ is the average energy of the radionuclide spectrum $(\mathrm{MeV}) ; q$ is the concentration $\left(\mathrm{Bq} \mathrm{g}^{-1}\right) ; k$ is the coefficient for $\mathrm{MeV}$ conversion into Joules $\left(1.6 \times 10^{-13} \mathrm{~J} \mathrm{MeV}^{-1}\right) ; T=86,400 \mathrm{~s}$ (number of seconds in a 24 hours period).

For objects with linear dimensions that are lower than the maximum range in the tissue (1 - $10 \mathrm{~mm}$ ), such approximation will provide an overestimated assessment of the absorbed dose because some of the energy will be released outside, depending on the geometric size, energy spectrum of the beta-particles, and the atomic composition. In this case, it mostly applies to the ${ }^{90} \mathrm{Y}$ incorporated into the skeleton. It is very difficult to estimate how much energy from the ${ }^{90} \mathrm{Y}$ will stay in the skeleton, how much will transfer to other tissues and how much will be released from the animal. Therefore, it was assumed that $70-80 \%$ of the ${ }^{90} \mathrm{Y}$ energy is released from the bones if their cross section is about $1.2 \mathrm{~mm}$. For the calculations of the absorbed dose for bone in Eqn (9), 0.3-0.4 MeV were used for the values $E_{\text {ef }}$ instead of $1.1 \mathrm{MeV}$ for $E_{\text {aveg }}$ for ${ }^{90} \mathrm{Sr}+{ }^{90} \mathrm{Y}$, and the remaining energy was distributed throughout the entire body (soft tissues).

To calculate the dose rates in the skeleton and soft tissues of the animal, it is necessary to know the ratio of masses of these tissues and patterns of the radionuclide distributions between 
them. In this study the following assumptions was made based on the earlier results of Baryakhtar et al. (2003) and Maklyuk et al. (2007):

1. The ${ }^{137}$ Cs concentration in the body is, on the average, equal to the concentration in the muscles.

2. The ${ }^{137}$ Cs concentration in the skeleton is 0.72 of the concentration in the muscles.

3. The ${ }^{90} \mathrm{Sr}$ concentration in the skeleton is 11 times higher than the average concentration in the body.

4. The ${ }^{90} \mathrm{Sr}$ concentration in the skeleton is 165 times higher than the concentration in the muscles.

The factors stated in the assumptions were used for the calculations because the initial values were the concentrations of the radionuclides in the entire body of the animal. Finally, as in many other studies on this topic, an a priori simplified approach was applied stating an assumption of a quasi-equilibrium state between the processes of the radionuclide intake and excretion in the bodies of wild animals. Table 9 provides the results of these calculations for three different soil type areas that were sampled for this study.

In Area 1, the absorbed dose during the 24 hour period reached 2 - 9 mGy. Considering the fact that geometric means were used for the calculations, it can safely be stated that some species of the local population (up to $30 \%$ ) received an absorbed dose of over $10 \mathrm{mGy}$ day ${ }^{-1}$. In Area 2, the absorbed doses appeared to be lower by factors 3 - 14 and in Area 3, lower by factors $3-5$ than in Area 2.

The internal radiation of the animals presented the largest contribution to the absorbed dose $(40-88 \%)$, with the roles of the incorporated ${ }^{90} \mathrm{Sr}$ and ${ }^{137} \mathrm{Cs}$ depending on species specific characteristics of the animals. For example, in most cases, the ${ }^{137} \mathrm{Cs}$ concentration in the body of 
bank voles significantly exceeded the ${ }^{137} \mathrm{Cs}$ concentration in other species, making this radionuclide the major contributor to the dose (up to $79 \%$ for Area 1). However, in other sites, it

was mostly the ${ }^{90} \mathrm{Sr}$ content that was the major contributor to the doses for both the bank voles and other species $(29-55 \%)$.

Environmental non-radiation conditions also affected the doses. Table 9 shows that the contribution of the incorporated ${ }^{137} \mathrm{Cs}$ was the largest in Area 1, lower in Area 2 and even lower in Area 3. The humidity and acidity of the soils in those sites followed the same descending order: peat bog soils (Area 1) > low podsolic soils with occasional clay sandy soils (Area 2) > dry low podzolic gleic sandy loam soils (Area 3). The contribution of the incorporated ${ }^{90} \mathrm{Sr}$ changed in the reverse order.

The absorbed dose calculations performed in this study were consistent with the values obtained in the concurrent study (Beresford et al. 2008) but only for the doses from the external sources (Table 10). The assessment of the total absorbed dose from the external and internal sources appeared to be 1.5 - 2 times lower in the present study which might have been associated with an a priori conservative approach of the ERICA Tool software package.

\section{DISCUSSION AND CONCLUSIONS}

The total absorbed dose rates in small mammals significantly reduced during the years following the ChNPP accident. In 1986, the absorbed dose rate reached $1.3-6.0 \mathrm{~Gy} \mathrm{hr}^{-1}$ (Taskaev et al. 1990, Ukrainian Bureau of International Projects 1996) in the central areas of the ChEZ (the "Red Forest"). In 1988 and 1990, the total absorbed dose rates were equal to 1.3 and $0.42 \mathrm{~Gy} \mathrm{hr}^{-1}$, respectively (Ukrainian Bureau of International Projects, 1996). In 1995, 2000, and 
2005, according to the present study, the total absorbed dose rates rarely exceeded 0.00023 , 0.00018 , and $0.00015 \mathrm{~Gy} \mathrm{hr}^{-1}$, respectively. The major reasons for the absorbed dose rate decrease were associated with decay of short-lived gamma- and beta-emitters and transport of the major radionuclide inventory into the soils. In addition, during this time, a regular change in the percent of contributions of the external and internal radiation took place. In 1986, the contribution of the incorporated radionuclides into the absorbed dose was only $0.01 \%$ on the average (Fig. 4) while the contribution of the external beta-radiation exceeded $97 \%$ (Taskaev et al. 1990). By the summer of 1989, these values were about 3.2 and $87.1 \%$, respectively (Institute of Zoology of the National Academy of Science of Ukraine 1994). By mid-1990's, the contribution of the incorporated radionuclides became about $30 \%$ of the total absorbed dose (Chesser et al. 2000). Finally, in 2005, the contribution of the incorporated ${ }^{90} \mathrm{Sr}$ and ${ }^{137} \mathrm{Cs}$ (with some exceptions) was recorded to be $55 \%$ of the total absorbed dose for the body, with the external beta-radiation being about $21 \%$ and external gamma-radiation 23\% (Fig. 4).

In conclusion, the relationships between the dose rates identified in this study and the dose rates that will cause negative effects in populations of wild animals should be noted. Numerous laboratory and field studies conducted during the last few decades have shown that only chronic doses exceeding $100 \mathrm{mGy} \mathrm{d}^{-1}$ are capable of causing a significant increase in the mortality rate of small mammals (Chesser et al. 2000; Pryakhin et al. 2000; Suschenya et al. 1995; Sokolov et al. 1994). Radiation doses exceeding $10 \mathrm{mGy} \mathrm{d}^{-1}$ disrupt reproductive functions of the animals (Gaychenko et al. 2001; Suschenya et al. 1990, 1995). In the range from higher than the background values to $10 \mathrm{cGy}$, genetic effects in sexual and somatic cells of small mammals were recorded (Pomerantseva et al. 2006; Goncharova et al. 1999). Finally, according to the IAEA recommendations (1992), the maximum allowable dose rate for populations of wild 
mammals is $1 \mathrm{mGy}$ day $^{-1}$. This study shows that currently, in most contaminated areas of the ChEZ (total area of less than $30 \mathrm{~km}^{2}$ ), the dose rates for selected species of small mammals can reach $2-9$, and sometimes - up to $10-50 \mathrm{mGy} \mathrm{d}^{-1}$ (Chesser et al. 2000), primarily due to the incorporated radionuclides. However, due to the logarithmically normal distribution of most of the values which is characteristic of the ChEZ, it can be safely stated that the majority of the wildlife will have much lower dose rates. Outside the central part of the ChEZ, doses over 0.1 mGy $\mathrm{d}^{-1}$ are unlikely. Nevertheless, occasional publications that address negative biological effects in wild species associated with higher than natural background values demonstrate that it is still too early to declare studies of the post-Chernobyl effects complete. Assessment of radiobiological consequences of the ChNPP accident, including long-term consequences, is a challenging task requiring long-term comprehensive observations that will have to necessarily include dose rate assessments and evaluation of species specific characteristics.

Acknowledgments - The authors would like to thank Ines Triay, Yvette Collazo, Kurt Gerdes, and Ana Han for their support of the U.S. Department of Energy Office of Environmental Management's International Cooperative Program with IRL. The authors would also like to express their gratitude to Tatyana Albert (Thomas E. Albert and Associates, Inc.) for translating documents and reports prepared at SRNL and IRL.

Disclaimer - This manuscript has been co-authored by Savannah River Nuclear Solutions, LLC under Contract No. DE-AC09-08SR22470 with the U.S. Department of Energy. The United States Government retains and the publisher, by accepting this article for publication, acknowledges that the United States Government retains a non-exclusive, paid-up, irrevocable, 
worldwide license to publish or reproduce the published form of this work, or allow others to do so, for United States Government purposes. Mention of trade names or commercial products does not constitute endorsement or recommendation for use by the authors or their corresponding organizations.

\section{REFERENCES}

Aleksakhin RM. Nuclear energy and biosphere. Moscow: Energoatomizdat; 1982: 1-216.

Baker RJ, Bickham AM, Bondarkov M, Gaschak SP, Matson CW, Rodgers BE, Wickliffe JK, Chesser RK. Consequences of Polluted Environments on Population Structure: The Bank Vole (Clethrionomys glareolus) at Chornobyl. Ecotoxicology 10:211-216; 2001.

Balabukha VS, Razbitnaya LM, Razumovsky NO, Tikhonova LI.. Problem of excretion of longlived radioactive isotopes from the body. Gosatomizdat 1962:168.

Baryakhtar VG, Bondarkov MD, Gaschak SP, Goryanaya JA, Maximenko AM, Liabik VV, Chesser RK, Baker RG. Problems in small mammals radioecology. Environ Sci Pollut Res 1:95-106; 2003.

Bazhenov VA, Buldakov LA, Vasilenko IY, Zhuravlev VF, Zaikina TI, Kalistratova VA, Moskalev YI, Osipov VA, Stepanov SV, Filov VA. Hazardous chemicals: Radioactive substances. Khimiya 1990:464.

Beresford NA, Gaschak S, Barnett CL, Howard BJ, Chizhevsky I, Strømann G, Oughton DH, Wright SM, Copplestone D, Maksimenko A. Estimating the exposure of small mammals at three sites within the Chernobyl exclusion zone - a test application of the ERICA Tool. J Environ Radioact 99:1496-1502; 2008.

Bondarkov MD, Maximenko AM, Zheltonozhsky VA. Non radiochemical technique for $90 \mathrm{Sr}$ measurement. In: The Radioecology-ecotoxicology of continental and estuarine environments, ECORAD 2001: International Congress 3-7 Sept. 2001: proc. cong. Aixen-Provence, France, 2002. Radioprotection-Colloques. 37 (C1): 927-931.

Bondarkov MD, Gaschak SP, Goryanaya JA, Maximenko AM, Chesser RK, Baker RG. Radionuclides accumulation and dose burden in small mammals in Chornobyl zone. In: Contributed papers of International Conference on the protection of the environment from the effects of ionizing radiation. Stockholm, Sweden: IAEA-CN-109/100; 2003: 237241.

Bondarkov MD, Maksimenko AM, Gashchak SP, Zheltonozhsky VA, Jannik GT, Farfán EB. Method for simultaneous in vivo $90 \mathrm{Sr}$ and $137 \mathrm{Cs}$ content measurements in bodies of small animals and other environmental objects developed for conditions of the Chernobyl Exclusion Zone. Health Phys 2011: (In Press).

Buldakov LA, Moskalev YI. Problem of distribution and experimental assessments of allowable limits for 137Cs, 90Sr, and 106Ru. Atomizdat 1968:295. 
Chesser RK, Sugg DW, Lomakin MD, Van Den Bussche RA, DeWoody JA, Jagoe CH, Dallas CE, Whicker FW, Smith MH, Gashchak SP, Chizhevsky IV, Lyabik VV, Buntova EG, Holloman K, Baker RJ. Concentrations and dose rate estimates of 134, 137Cesium and 90Strontium in small mammals at Chernobyl. Environ Toxicol Chem 19:305-312; 2000.

Chesser RK, Rodgers BE, Wickliffe JK, Phillips CJ, Gaschak S, Baker RJ. Accumulation of 137Cesium and 90Strontium through abiotic and biotic pathways in rodents at Chernobyl. Environ Toxicol Chem 20:1927-1935; 2001.

Gaychenko VA. 137Cs migration in the pasture type trophic chain. Ecologo-fauna studies in the ChNPP area. UkrRNPF Meditsina-Ecologiya; 1995: 3-17.

Gaychenko VA, Koval GM, Titar VM. Patterns of presence and biological redistribution of radionuclides, their migration in trophic chains for generation of dose rates in wild animals. In: Baryakhtar VG, ed. Chernobyl exclusion zone: Collection of scientific articles. Naukova Dumka; 2001: 299-316.

Gashchak SP, Maklyuk YA, Maksimenko AM, Maksimenko VM, Martynenko VI, Chizhevsky IV, Bondarkov MD, Mousseau TA. Patterns of radioactive contamination of small birds in the Chernobyl Zone in 2003 - 2005. Radiats Biol Radioecol 48:28-47; 2008.

Goncharova RI, Ryabokon NI, Smolich II. Biological effects of low-dose chronic irradiation in somatic cells of small mammals. In: Gossens LHJ, ed. Risk analysis: Facing the new millennium. Proceedings of $9^{\text {th }}$ Annual Conference. Rotterdam: Delft University Press 1999: 710-714.

Ilyenko AI. Ecology of mammals and birds. Nauka 1967:122-126.

Ilyenko AI. Concentrating radioisotopes by animals and their effect on the population. Nauka 1974: 168.

Ilyenko AI, Krapivko TP. Results of radioecological monitoring of the bank vole population after the Chernobyl accident. Zoological Journal 77:108-116; 1998.

International Atomic Energy Agency. Effects of ionizing radiation on plants and animals at levels implied by current radiation protection standards. Vienna: IAEA Publication; Technical Report Series No. 332; 1992.

Ivanov YA. Dynamics of redistribution of radionuclides in soils and vegetation. Chernobyl. In: Baryakhtar VG, ed. Exclusion Zone: collection of scientific articles. Kiev: Naukova Dumka; 2001: 47-76.

Ivanov YA, Kashparov VA. Long-term dynamics of radioecological situation in terrestrial ecosystems on the territory of Exclusion Zone. Environ Sci Pollut Res 1:13-20; 2003.

Kashparov VA, Oughton DH, Zvarich SI, Protsak VP, Levchuk SE. Kinetics of fuel particle weathering and 90Sr mobility in the Chernobyl 30-km exclusion zone. Health Phys 76:251-259; 1999.

Kaye SV, Dunaway PB. Bioaccumulation of radioactive isotopes by herbivorous small mammals. Health Phys 7:205-217; 1962.

Korneev NA, Sirotkin AN. Fundamentals of radioecology of agricultural animals. Moscow: Energoatomizdat; 1987: 30-56.

Kozlo PG, Kuchmel' SV, Emelyanova LG, Deryabina TG. Temporal changes in the radionuclide content in wild boar (Suc scrofa) and elk (Alges alges) species. In: Odinstova TM, Kireenko KM, eds. $10^{\text {th }}$ Anniversary of the Polesye State Radiation Ecological Preserve, Collection of Articles. Minsk: 1998: 53-59.

Kozlov VF. Reference book on radiation safety, $3^{\text {rd }}$ ed. Moscow: Energoatomizdat; 1987. 
Matson CW, Rodgers BE, Chesser RK, Baker RJ. Genetic diversity of Clethrionomys glareolus populations from highly contaminated sites in the Chernobyl region, Ukraine. Environ Toxicol Chem 19:2130-2135; 2000.

Maklyuk YA, Gashchak SP, Lipskaya AI, Maksimenko AM. Assessments of 90Sr and 137Cs distribution in organs and tissues of bank voles (Clethrionomys glareolus) under the conditions of the Chernobyl Zone. Nuclear Physics and Energy 18:115 - 123; 2006.

Maklyuk YA, Gashchak SP, Maksimenko AM, Bondarkov MD. In Vivo assessments of parameters for $90 \mathrm{Sr}$ and $137 \mathrm{Cs}$ excretion from bodies of wild and laboratory animals after their natural contamination in the Chernobyl Zone. Radiats Biol Radioecol 47:530 - 542; 2007a.

Maklyuk YA, Gashchak SP, Maksimenko AM, Bondarkov MD, Beresford N. Value and structure of dose rates in small mammals of the Chernobyl Zone 19 years after the accident. Nuclear Physics and Energy 21:81 - 91; 2007b.

Maklyuk YA, Maksimenko AM, Gashchak SP, Bondarkov MD, Chizhevsky IV. Long-term dynamics of radioactive contamination (90Sr and 137Cs) of small mammals in the Chernobyl Zone. Ecology 38:198 - 206; 2007c.

Moiseev AA, Ivanov VI. Reference book on dosimery and radiation hygiene, $4^{\text {th }}$ ed. Moscow: Energoatomizdat; 1990.

Moskalev YI. Radiobiology of incorporated radionuclides. Moscow: Energoatomizdat; 1989.

Oleksyk TK, Gashchak SP, Glenn TC, Jagoe CH, Peles JD, Purdue JR, Tsyusko OV, Zalissky OO, Smith MH. Frequency distributions of $137 \mathrm{Cs}$ in fish and mammal populations. J Environ Radioact 61:55-74; 2002.

Oleksyk TK, Novak JM, Perdue JR, Gashchak SP, Smith MH. High levels of fluctuating asymmetry in populations of Apodemus flavicollis from the most contaminated areas in Chernobyl. J Environ Radioact 73:1-20; 2004.

Osanov DP. Dosimetry and radiation biophysics of the skin. Moscow: Energoatomizdat; 1990.

Pomerantseva MD, Ramaya LK, Rubanovich AV, Shevchenko VA. Genetic consequences of increased radiation background for murine rodents. Radiats Biol Radioecol 46:279 - 286; 2006.

Pryakhin EA, Shvedov VL, Akleev AV. Assessments of effects of dose rates and absorbed doses on long-term radiation related consequences for rats associated with the chronic $90 \mathrm{Sr}$ intake. Radiats Biol Radioecol 42:412 - 418; 2002.

Richmond CR. Retention and excretion of radionuclides of the alkali metals by five mammalian species. Health Phys 38:1111-1153; 1980.

Rodgers BE, Baker RJ. Micronucleus frequencies of Clethrionomys glareolus from zones of high radiation at Chernobyl. Environ Toxicol Chem 19:1644-1649; 2000.

Rodgers BE, Wickliffe JK, Phillips CJ, Chesser RK, Baker RJ. Experimental exposure of naive bank voles, Clethrionomys glareolus, to the Chornobyl environment: A test of radioresistance. Environ Toxicol Chem 20:1936-1941; 2001.

Rozhdestvenskaya AS. Small mammals. In: Suschenya LM, Pikulik MM, Plenina AE, eds. Animal world in the area of the Chernobyl NPP accident. Nauka i tekhnika 1995:68 - 74 .

Rozhdestvenskaya AS, Samusenko EG, Goncharova RI, Levina AB, Zabreyko SP, Ryabokon NI. Characteristics of small mammals from the ChNPP accident area. In: Senin EV, ed. Proceedings of the $1^{\text {st }}$ International Conference: Biological and Radioecological Aspects of the Consequences of the ChNPP Accident Radioecology of plants. Radioecology of terrestrial animals. Radioecology of hydorbionts. Zeleny Mys, 1990: 233-246.

Radiation Ecology Issues Associated with Murine Rodents and Shrews in the ChEZ 
Rozhdestvenskaya AS. Reproduction of European bank voles under the conditions of the environmental contamination with radiocesium in Belorussia. In: Bio-indication of radioactive contaminations. Minsk: Nauka; 1999: 226-231.

Ryabokon NI, Smolich II, Kudryashov VP, Goncharova RI. Long-term development of the radionuclide exposure of murine rodent populations in Belarus after the Chernobyl accident. Radiat Environ Biophys 44:169-181; 2005.

Schmalhauzen Institute of Zoology of the NAS of Ukraine. Study changes in the species composition of animals in areas of radioactive contamination. In: Study degrees of damage of communities and ecosystems. Kiev: Report on Agreement 94/3.3.1.1./57; 1994.

Schmidt-Nielsen K. Animal sizes: why are they so important? Moscow: Mir; 1987:259.

Starichenko VI, Lubashevsky NM. Individual characteristics of 90Sr accumulation in bodies of two species of common voles inhabiting the area of the Eastern Urals plume. Radiats Biol Radioecol 38:375 - 383; 1998.

Sokolov VE, Ryabov IN, Ryabtsev IA, Kulikov AO, Tichomirov FA, Sheheglov AI. Effects of radioactive contamination on the flora and fauna in the vicinity of Chernobyl nuclear power plant. In: Turpaev TM ed. Soviet Scientific Reviews, Section F, Physiology and general biology reviews. Harwood Academic Publishers GmbH; 1994: 1-124.

Suschenya LM, Pikulik MM, Plenina AE. Assessment of radiobiological consequences in the fauna of the Chernobyl NPP accident. In: Senin EV, ed. Proceedings of the $1^{\text {st }}$ International Conference: Biological and Radioecological Aspects of Consequences of the Chernobyl NPP Accident. Radioecology of plants. Radioecology of terrestrial animals. Radioecology of hydrobionts. Zeleny Mys 1990: 137-159.

Suschenya LM (editor), Pikulik MM, Plenina AE. Animal world in the area of the Chernobyl NPP accident. Minsk: Nauka i tekhnika 1995:263.

Taskaev AI, Testov BV, Pomerantseva MD, Chekhovich AI. Formation of radiation doses for murine rodents. In: Radioecological aspects of the ChNPP accident consequences. Proceedings of the $2^{\text {nd }}$ Scientific and Technical Meeting on the Results of the Mitigation of the ChNPP Accident. 1990: 475-488.

Tikhomirov FA. Tasks of health physics in the radioecology. In: Klechkovsky VM, Polikarpov GG, Aleksakhin RM, eds. Modern problems of radiobiology. Radioecology. Moscow: Atomizdat 1971: pp. $261-279$.

Ukrainian Bureau of International Projects. Summary of data for 1987 - 1995 on effects of ionizing radiation on hydrobionts and terrestrial vertebrates on population, organism, tissue and cytogenetic levels. Kiev; Report on Agreement \# 95/2.5-2.6/21 (01.05.95); 1996: 1-60.

Vandecasteele CM, Van Hees M, Culot JP, Vankerkom J. Radiocesium metabolism in pregnant ewes and their progeny. Sci Total Environ 85:213-223; 1989.

Voytovich AM. Ecologo-genetic monitoring of small vertebrates. In: Odintsova TM, Kireenko KM, eds. Collection of Articles. $10^{\text {th }}$ Anniversary of the Polesye State Radiation Ecological Preserv. Minsk: 1998; 206-214.

Voytovich AM. Small vertebrates in the radioecological monitoring after the ChNPP accident. In: Problems of ecology and ecological education of the Polesye Region in the postChernobyl period. Proceedings of the International Scientific Conference. RIF Bely Veter ; 2000: 146 - 152 . 
Wickliffe JK, Chesser RK, Rodgers BE, Baker RJ. Assessing the genotoxicity of chronic, environmental irradiation using mitochondrial DNA heteroplasmy in the bank vole (Clethrionomys glareolus) at Chernobyl. Environ Mol Mutagen 21:1249-1254; 2002.

Wiggins LE, Van Den Bussche RA, Hamilton MJ, Chesser RK, Baker RJ. Utility of chromosomal position of heterochromatin as a biomarker of radiation-induced genetic damage: a study of Chernobyl voles (Microtus sp.). Ecotoxicology 11:147-154; 2002. 


\section{FIGURE CAPTIONS}

Fig.1. Interspecies differences in the ${ }^{137} \mathrm{Cs}$ soil-to-animal transfer coefficient $\left(T_{a g}\right)$ in small mammals in the Lake Glubokoe Area of the ChEZ in 1995, 1998, and $2000\left(T_{a g}\right.$ geom. \pm $\left.\mathrm{SD}_{\text {geom. }}\right)$.

Fig. 2. Interspecies differences in the ${ }^{137} \mathrm{Cs}$ soil-to-animal transfer coefficient $\left(T_{a g}\right)$ in small mammals in the Red Forest Area of the ChEZ in 1997, 2001, and 2002 ( $T_{\text {ag geom. }} \pm$ $\left.\mathrm{SD}_{\text {geom. }}\right)$.

Fig. $3 .{ }^{137} \mathrm{Cs}$ soil-to-animal transfer coefficient $\left(T_{a g}\right)$ for the bank voles sampling set $(\mathrm{n}=541)$ in the Red Forest Area in May - September $1997-2003, T_{\text {ag geom. }} \pm \mathrm{SD}_{\text {geom }}$.

Fig. 4. Contributions ( $\%$ of dose) of various radiation sources into the total absorbed dose for murine rodents in the Chernobyl Exclusion Zone in 1986 - 2005. 


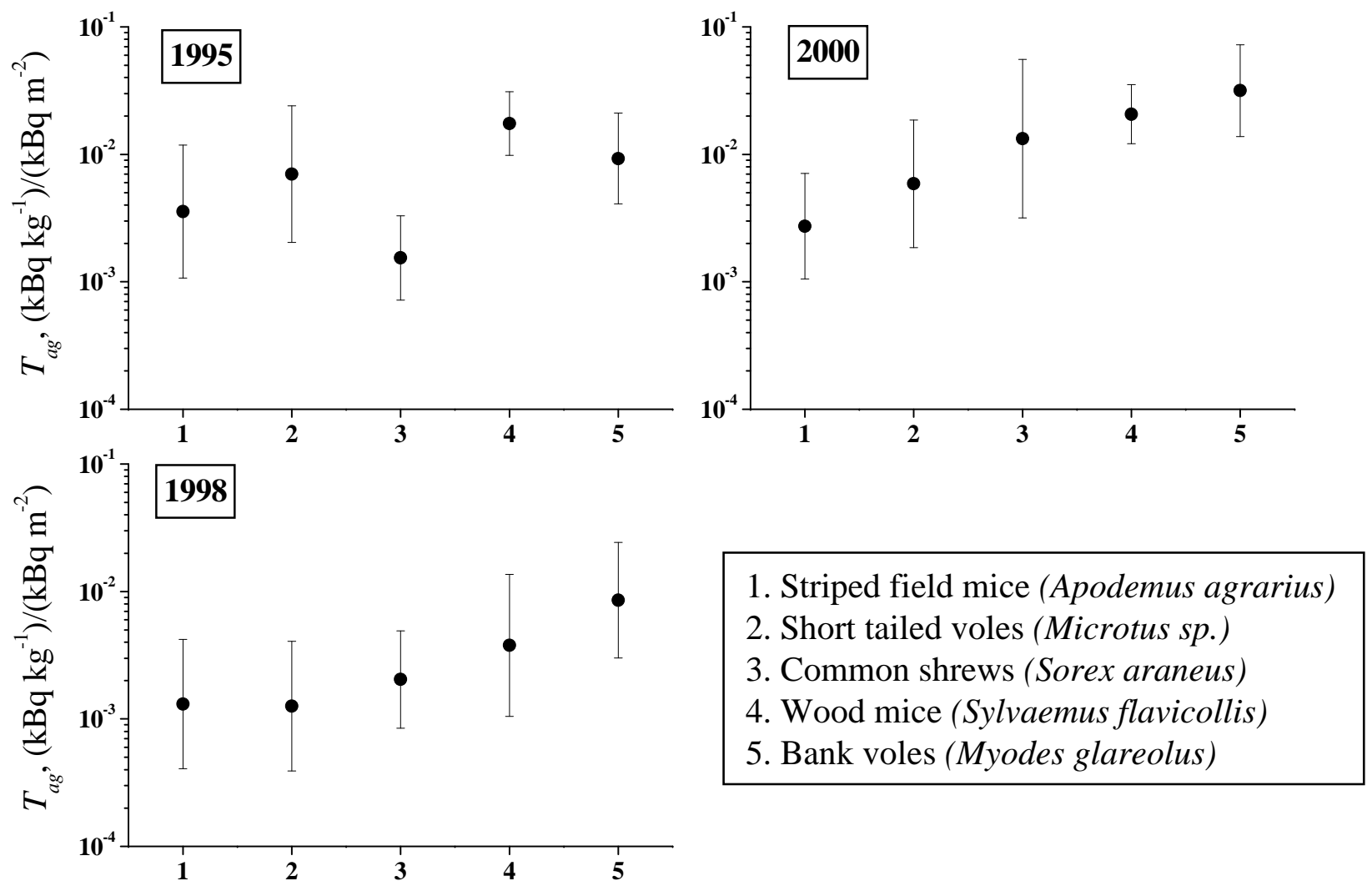

Fig.1. Interspecies differences in the ${ }^{137} \mathrm{Cs}$ soil-to-animal transfer coefficient $\left(T_{a g}\right)$ in small mammals in the Lake Glubokoe Area of the ChEZ in 1995, 1998, and $2000\left(T_{a g}\right.$ geom. $\left.\pm \mathrm{SD}_{\text {geom. }}\right)$. 

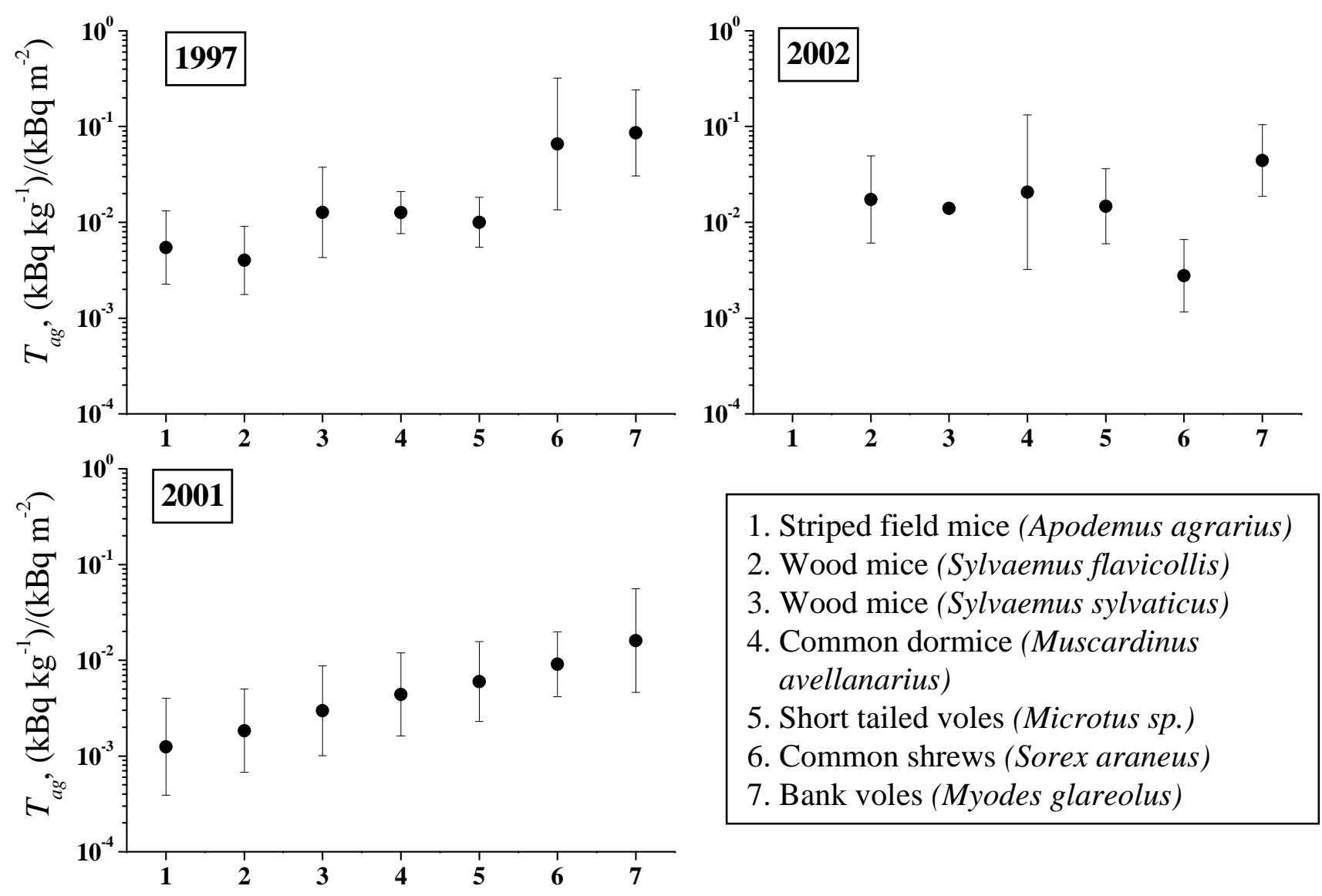

1. Striped field mice (Apodemus agrarius)

2. Wood mice (Sylvaemus flavicollis)

3. Wood mice (Sylvaemus sylvaticus)

4. Common dormice (Muscardinus avellanarius)

5. Short tailed voles (Microtus sp.)

6. Common shrews (Sorex araneus)

7. Bank voles (Myodes glareolus)

Fig. 2. Interspecies differences in the ${ }^{137} \mathrm{Cs}$ soil-to-animal transfer coefficient $\left(T_{a g}\right)$ in small mammals in the Red Forest Area of the ChEZ in 1997, 2001, and 2002 ( $T_{a g}$ geom. $\left.\pm \mathrm{SD}_{\text {geom. }}\right)$. 


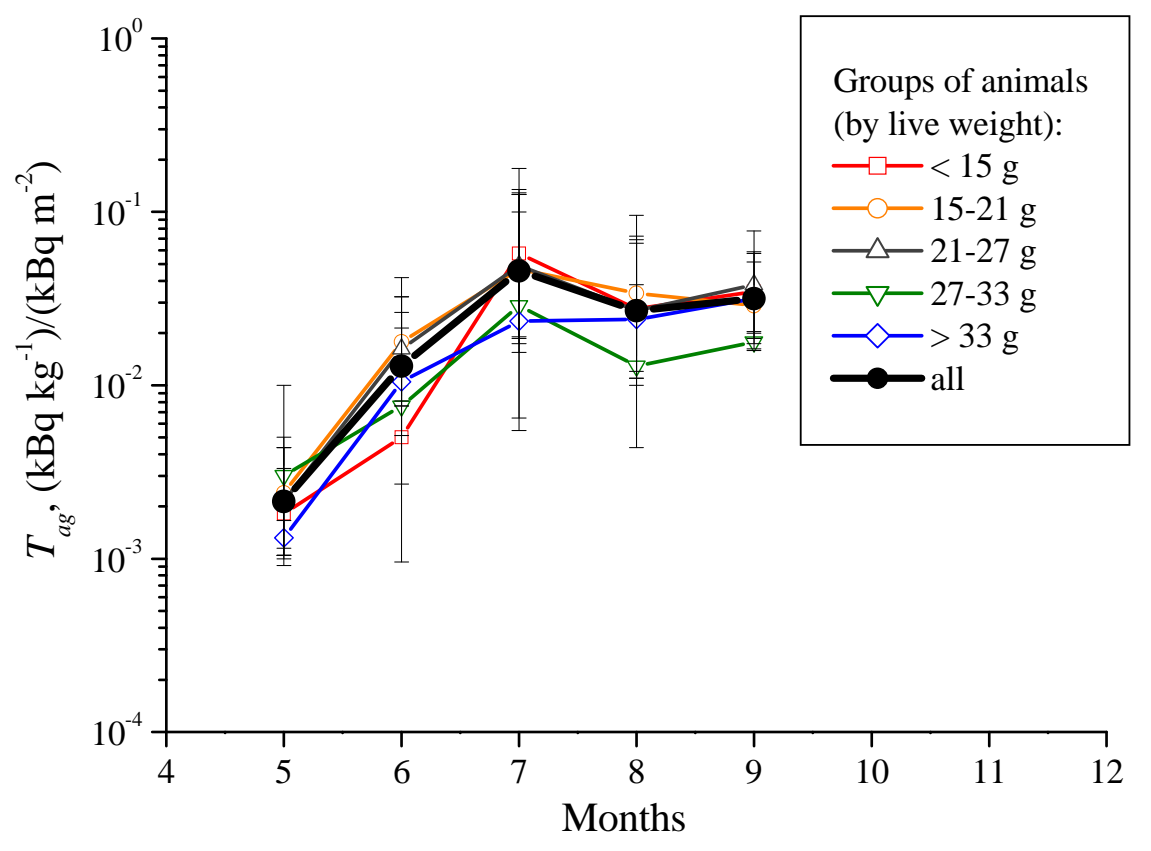

Fig. 3. ${ }^{137} \mathrm{Cs}$ soil-to-animal transfer coefficient $\left(T_{a g}\right)$ for the bank voles sampling set $(\mathrm{n}=541)$ in the Red Forest Area in May - September $1997-2003, T_{a g}$ geom. $\pm \mathrm{SD}_{\text {geom. }}$ 


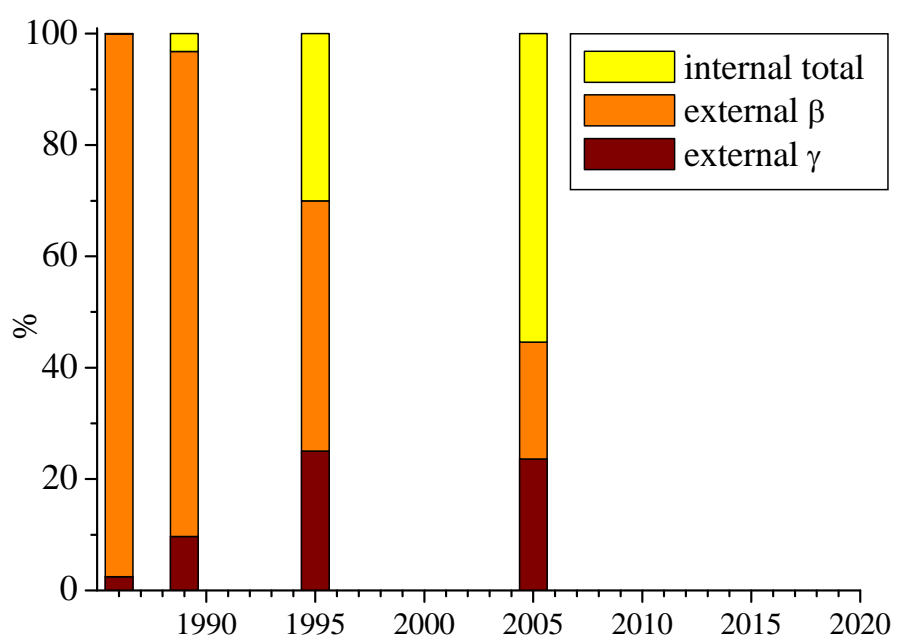

Fig. 4. Contributions (\% of dose) of various radiation sources into the total absorbed dose for murine rodents in the Chernobyl Exclusion Zone in 1986 - 2005. 
Table 1. Average long-term dynamics of the transfer coefficient $\left(T_{a g}\right)$ for ${ }^{90} \mathrm{Sr}$ and ${ }^{137} \mathrm{Cs}$ in the soil-to-animal chain for all murine rodent species of the Chernobyl Exclusion Zone, $\times 10^{-3}(\mathrm{kBq}$ $\left.\mathrm{kg}^{-1}\right) /\left(\mathrm{kBq} \mathrm{m}^{-2}\right)$.

\begin{tabular}{|c|c|c|c|c|c|c|c|c|}
\hline \multirow{2}{*}{ Year } & \multicolumn{4}{|c|}{${ }^{137} \mathrm{Cs}$} & \multicolumn{4}{|c|}{${ }^{90} \mathrm{Sr}$} \\
\hline & Mean $_{\text {geom }}{ }^{a}$ & Range $^{\mathrm{b}}$ & $S D_{\text {geom }}{ }^{\mathrm{c}}$ & $n^{d}$ & Mean $_{\text {geom }}{ }^{\mathrm{a}}$ & Range $^{\mathrm{b}}$ & $S D_{\text {geom }}{ }^{\mathrm{C}}$ & $n^{d}$ \\
\hline $1986^{\mathrm{e}}$ & 26.1 & $5.31-287.6$ & 4.01 & 7 & & & & \\
\hline $1987^{\mathrm{e}}$ & 14.4 & $3.04-113.9$ & 3.50 & 7 & & & & \\
\hline $1988^{\mathrm{e}}$ & 34.3 & $5.22-135.6$ & 2.61 & 11 & 17.67 & $3.15-47.8$ & 2.41 & 8 \\
\hline $1989^{\mathrm{e}}$ & 27.6 & $7.99-271.3$ & 3.38 & 8 & & & & \\
\hline $1990^{\mathrm{e}}$ & 112.8 & $6.23-1427.8$ & 5.54 & 9 & & & & \\
\hline $1991^{\mathrm{e}}$ & 22.4 & $7.57-65.6$ & 2.25 & 6 & 1.83 & $0.66-3.20$ & 2.41 & 3 \\
\hline $1992^{\mathrm{e}}$ & 12.8 & $5.99-29.1$ & 2.21 & 3 & & & & \\
\hline $1993^{\mathrm{e}}$ & 2.14 & $1.70-2.70$ & & 2 & 1.28 & & & 1 \\
\hline $1994^{\mathrm{e}}$ & 8.09 & & & 1 & & & & \\
\hline 1995 & 2.13 & $0.09-396.8$ & 5.36 & 167 & 1.10 & $0.07-56.0$ & 3.82 & 130 \\
\hline 1996 & 0.46 & $0.03-160.2$ & 4.78 & 101 & 0.26 & $0.02-13.8$ & 3.61 & 71 \\
\hline 1997 & 10.7 & $0.02-1159.7$ & 8.94 & 484 & 0.46 & $0.01-35.4$ & 3.70 & 222 \\
\hline 1998 & 1.66 & $0.05-29.8$ & 4.52 & 113 & 0.88 & $0.01-8.2$ & 4.10 & 31 \\
\hline 1999 & 1.59 & $0.04-64.8$ & 4.14 & 219 & 4.30 & $0.78-13.4$ & 2.05 & 28 \\
\hline 2000 & 21.9 & $0.56-522.1$ & 4.32 & 221 & 5.43 & $0.15-156.1$ & 3.67 & 53 \\
\hline 2001 & 5.30 & $0.08-183.7$ & 4.85 & 712 & 3.08 & $0.45-13.2$ & 2.43 & 37 \\
\hline 2002 & 25.7 & $0.83-816.9$ & 3.59 & 267 & 5.94 & $0.57-35.0$ & 2.29 & 196 \\
\hline 2003 & 15.9 & $0.92-156.8$ & 2.93 & 109 & 2.01 & $0.08-23.3$ & 2.70 & 109 \\
\hline 2004 & 1.19 & $0.01-21.0$ & 6.43 & 76 & 2.56 & $0.55-88.3$ & 2.75 & 76 \\
\hline 2005 & 5.99 & $0.24-385.1$ & 3.86 & 561 & 7.51 & $0.28-158.8$ & 2.30 & 561 \\
\hline
\end{tabular}

${ }^{\mathrm{a}}$ Mean geom. is an average geometric mean.

${ }^{\mathrm{b}}$ Range is a range of values.

${ }^{\mathrm{c}} \mathrm{SD}_{\text {geom. }}$. is a standard geometric deviation

${ }^{\mathrm{d}} \mathrm{n}$ is a number of data in the sampling size.

${ }^{\mathrm{e}}$ indicates processing of the literature data only. 
Table 2. Soil-to-animal (bank voles) transfer coefficients $\left(T_{a g}\right)$ for ${ }^{90} \mathrm{Sr}$ and ${ }^{137} \mathrm{Cs}$ in four areas of the ChEZ in July 2002, $\left(\mathrm{kBq} \mathrm{kg}^{-1}\right) /\left(\mathrm{kBq} \mathrm{m}^{-2}\right)$.

\begin{tabular}{|c|c|c|c|c|}
\hline \multirow{2}{*}{ Characteristics } & \multicolumn{4}{|c|}{ Areas } \\
\hline & 1 & 2 & 3 & 4 \\
\hline $\begin{array}{l}\text { Type of soils and } \\
\text { moisture content in } \\
\text { the } 0-10 \mathrm{~cm} \text { deep soil } \\
\text { layer, } \%\end{array}$ & $\begin{array}{c}\text { Sod gleic, } \\
\text { sandy loam } \\
\text { and clay sandy } \\
\text { soils, } 24 \% \\
\end{array}$ & $\begin{array}{c}\text { Sod low } \\
\text { podzolic, sandy } \\
\text { soils, } 6 \%\end{array}$ & $\begin{array}{l}\text { Sod medium } \\
\text { podzolic, loamy } \\
\text { soils, } 11 \%\end{array}$ & $\begin{array}{c}\text { Peat bog soils, } \\
30 \%\end{array}$ \\
\hline $\mathrm{N}$ & 19 & 15 & 29 & 22 \\
\hline \multicolumn{5}{|c|}{${ }^{90} \mathrm{Sr}$} \\
\hline$\overline{D \text { geom }}^{\mathrm{a}}, \mathrm{MBq} \mathrm{m}^{-2}$. & 0.04 & 1.1 & 3.8 & 56.4 \\
\hline$T_{a g \text { geom. }}, \times 10^{-3}$ & 15.1 & 12.2 & 3.2 & 3.9 \\
\hline Range $T_{a g}, \times 10^{-3}$ & 5.3-32.2 & $5.8-22.9$ & $0.8-11.7$ & $0.9-12.4$ \\
\hline \multicolumn{5}{|c|}{${ }^{137} \mathrm{Cs}$} \\
\hline$D_{\text {geom }}{ }^{\mathrm{a}}, \mathrm{MBq} \mathrm{m}{ }^{-2}$ & 0.1 & 4.1 & 9.2 & 84 \\
\hline$T_{a g \text { geom. }} \times 10^{-3}$ & 72.4 & 7.7 & 5.4 & 69.6 \\
\hline Range $T_{a q}, \times 10^{-3}$ & $31.7-817$ & $1.8-25.6$ & $1.4-24.6$ & $24.3-181.0$ \\
\hline
\end{tabular}


Table 3. ${ }^{90}$ Sr transfer coefficient $\left(T_{a g}\right)$ in the soil-to-animal chain for various species of small mammals of the ChEZ in 1995 - 2005, $\left(\mathrm{kBq} \mathrm{kg}^{-1}\right) /\left(\mathrm{kBq} \mathrm{m}^{-2}\right)$.

\begin{tabular}{|c|c|c|c|c|c|}
\hline Location & Species & $\begin{array}{c}\text { Mean }^{\text {geom }}{ }^{\mathrm{a}} . \\
\left(\times 10^{-3}\right)\end{array}$ & $\mathbf{S D}_{\text {geom }}$ & $\begin{array}{c}\text { Range } T_{\text {ag }}{ }^{\mathrm{c}} \\
\left(\times 10^{-3}\right)\end{array}$ & $\mathbf{N}^{\mathbf{d}}$ \\
\hline \multirow{4}{*}{ Chistogalovka } & Striped field mice & 0.25 & 2.79 & $0.06-4.28$ & 22 \\
\hline & Bank voles & 0.23 & 3.92 & $0.08-4.94$ & 12 \\
\hline & Common Shrews & 0.71 & 2.72 & $0.39-11.84$ & 11 \\
\hline & Short tailed voles & 0.30 & 3.46 & $0.02-12.70$ & 71 \\
\hline \multirow{5}{*}{ Glubokoe Lake } & Striped field mice & 0.55 & 3.01 & $0.13-14.09$ & 15 \\
\hline & Bank voles & 0.57 & 2.42 & $0.17-14.20$ & 28 \\
\hline & Wood mice & 2.46 & 2.00 & $0.43-8.75$ & 27 \\
\hline & Common Shrews & 1.58 & 4.58 & $0.39-33.01$ & 9 \\
\hline & Short tailed voles & 4.11 & 4.15 & $0.94-55.96$ & 19 \\
\hline \multirow{4}{*}{ Izumrudnoe } & Bank voles & 9.73 & 2.90 & $0.58-54.36$ & 31 \\
\hline & Wood mice & 12.17 & 2.24 & $0.81-66.76$ & 98 \\
\hline & Common Shrews & 28.92 & 1.72 & $15.79-57.19$ & 5 \\
\hline & Short tailed voles & 14.77 & 1.68 & $4.28-29.60$ & 17 \\
\hline \multirow{4}{*}{$\begin{array}{l}\text { Novoshepelichskoe } \\
\text { (NSHP) Forestry }\end{array}$} & Striped field mice & 3.49 & 2.68 & $1.74-7.01$ & 2 \\
\hline & Bank voles & 5.48 & 2.11 & $0.28-26.04$ & 299 \\
\hline & Wood mice & 5.56 & 2.02 & $0.89-38.45$ & 44 \\
\hline & Common Shrews & 6.89 & 2.35 & $0.68-22.47$ & 33 \\
\hline \multirow{4}{*}{ Paryshev } & Striped field mice & 2.66 & 5.08 & $0.46-17.37$ & 5 \\
\hline & Bank voles & 3.37 & 3.98 & $0.77-107.00$ & 58 \\
\hline & Wood mice & 7.81 & 2.67 & $0.72-21.12$ & 16 \\
\hline & Common Shrews & 36.31 & 1.95 & $16.40-74.53$ & 5 \\
\hline \multirow{5}{*}{ Red Forest, Center } & Striped field mice & 2.65 & 1.64 & $1.87-3.75$ & 2 \\
\hline & Bank voles & 2.84 & 2.54 & $0.08-14.64$ & 139 \\
\hline & Wood mice & 0.89 & 6.73 & $0.04-12.34$ & 10 \\
\hline & Common Shrews & 6.35 & 1.89 & $1.97-19.42$ & 21 \\
\hline & Short tailed voles & 7.86 & 2.51 & $0.81-34.97$ & 18 \\
\hline \multirow{5}{*}{ Red Forest, West } & Striped field mice & 7.34 & 1.55 & $4.83-11.64$ & 3 \\
\hline & Bank voles & 6.88 & 2.22 & $0.53-25.04$ & 84 \\
\hline & Wood mice & 3.51 & 6.17 & $0.15-55.50$ & 9 \\
\hline & Common Shrews & 7.98 & 2.63 & $0.21-30.89$ & 65 \\
\hline & Short tailed voles & 8.16 & 2.29 & $0.42-158.83$ & 64 \\
\hline
\end{tabular}


Table 4. ${ }^{90} \mathrm{Sr}$ and ${ }^{137} \mathrm{Cs}$ transfer coefficients $\left(T_{a g}\right)$ in various age groups of bank voles in the NSHP Forestry $(\mathrm{kBq}$ $\left.\mathrm{kg}^{-1}\right) /\left(\mathrm{kBq} \mathrm{m}^{-2}\right)$.

\begin{tabular}{|c|c|c|c|c|c|c|c|c|c|c|c|c|}
\hline \multirow{3}{*}{ Date } & \multicolumn{12}{|c|}{ Size (age) groups } \\
\hline & \multicolumn{3}{|c|}{ Up to $15 \mathrm{~g}$} & \multicolumn{3}{|c|}{$15-21 \mathrm{~g}$} & \multicolumn{3}{|c|}{$21-27 g$} & \multicolumn{3}{|c|}{ Over 27 g } \\
\hline & Mean $_{\text {geom }}{ }^{\mathrm{a}}$ & $\mathrm{SD}_{\text {geom }}$ & $\mathbf{n}^{\mathrm{c}}$ & Mean geom $^{a}$ & SD geom & $\mathbf{n}^{\mathbf{c}}$ & Mean geom $^{2}$ & SD geom & $n^{c}$ & Mean geom & SD geom & $\mathbf{n}^{\mathrm{c}}$ \\
\hline \multicolumn{13}{|c|}{${ }^{90} \mathrm{Sr} \mathrm{T}_{a q}$} \\
\hline 05.07 .05 & 5.07 & 1.16 & 3 & 7.82 & 1.38 & 3 & 3.46 & 1.47 & 5 & 3.88 & 1.41 & 11 \\
\hline 13.07 .05 & 3.17 & 1.59 & 4 & 1.91 & 2.00 & 12 & 1.59 & 1.69 & 10 & 1.87 & 1.57 & 8 \\
\hline 19.07 .05 & 4.50 & 1.29 & 4 & 3.37 & 1.91 & 13 & 3.05 & 1.51 & 17 & 3.87 & 1.39 & 9 \\
\hline 26.07 .05 & 1.34 & 2.68 & 13 & 1.75 & 2.12 & 15 & 1.02 & 2.09 & 15 & 1.24 & 2.38 & 7 \\
\hline 02.08 .05 & 4.18 & 1.42 & 12 & 4.97 & 1.39 & 16 & 3.16 & 1.47 & 17 & 3.09 & 1.96 & 7 \\
\hline 08.08 .05 & 4.92 & 1.46 & 16 & 4.75 & 1.63 & 22 & 2.65 & 1.94 & 22 & 2.60 & 1.77 & 2 \\
\hline \multicolumn{13}{|c|}{${ }^{137} \mathrm{Cs} \mathrm{T}_{a q}$} \\
\hline 05.07 .05 & 4.91 & 4.62 & 3 & 1.61 & 1.57 & 3 & 3.52 & 2.02 & 5 & 3.88 & 2.14 & 11 \\
\hline 13.07 .05 & 4.70 & 2.42 & 4 & 2.53 & 1.98 & 12 & 4.52 & 1.95 & 10 & 4.00 & 1.81 & 8 \\
\hline 19.07.05 & 2.71 & 1.30 & 4 & 2.75 & 1.74 & 13 & 3.54 & 2.20 & 17 & 3.93 & 1.75 & 9 \\
\hline 26.07 .05 & 2.08 & 1.46 & 13 & 2.63 & 2.29 & 15 & 2.51 & 1.59 & 15 & 2.68 & 1.62 & 7 \\
\hline 02.08 .05 & 2.19 & 1.50 & 12 & 3.38 & 2.09 & 16 & 3.58 & 2.43 & 17 & 2.80 & 1.91 & 7 \\
\hline 08.08 .05 & 2.61 & 1.94 & 16 & 2.39 & 2.45 & 22 & 2.59 & 2.20 & 22 & 4.16 & 1.50 & 2 \\
\hline
\end{tabular}

\footnotetext{
Mean geom is an average geometric mean.

${ }^{\mathrm{b}} \mathrm{SD}_{\text {geom }}$ is a standard deviation.
}

${ }^{\mathrm{c}} n$ is a number of data in the sampling set. 
Table 5. Parameters of ${ }^{90} \mathrm{Sr}$ and ${ }^{137} \mathrm{Cs}$ excretion from murine rodents based on the exponential decrease single component model.

\begin{tabular}{|c|c|c|c|c|c|c|c|}
\hline \multirow{2}{*}{$\begin{array}{c}\text { Body } \\
\text { mass, g }\end{array}$} & \multicolumn{3}{|c|}{${ }^{90} \mathrm{Sr}$} & \multicolumn{3}{|c|}{${ }^{137} \mathrm{Cs}$} & \multirow{2}{*}{ Reference } \\
\hline & $a_{1}$ & $t_{1}$ & $a_{2}$ & $a_{1}$ & $t_{1}$ & $a_{2}$ & \\
\hline \multicolumn{8}{|c|}{ Bank vole } \\
\hline 21.3 & 0.56 & 11.7 & 0.44 & 0.99 & 2.18 & 0.007 & $\begin{array}{l}\text { Baryakhtar et al 2003; } \\
\text { Makluk et al., } 2007\end{array}$ \\
\hline 25.5 & & & & & 1.13 & & Ilyenko, Krapivko, 1998 \\
\hline \multicolumn{8}{|c|}{ Laboratory mice } \\
\hline 28.9 & 0.87 & 49.9 & 0.13 & 0.99 & 4.40 & 0.011 & $\begin{array}{l}\text { Baryakhtar et al 2003; } \\
\text { Makluk et al., } 2007\end{array}$ \\
\hline $25^{\mathrm{a}}$ & & & & & 4.0 & & Balabukha et al., 1962 \\
\hline 25 & & & & & $1.2-1.8$ & & Richmond 1980 \\
\hline $25^{\mathrm{a}}$ & & & & & 3.0 & & Bazhenov et al., 1990 \\
\hline
\end{tabular}

${ }^{a}$ An estimated body mass is stated since no indication of the body mass was found in the reference source. 
Table 6. Radiation conditions of the ChEZ areas where the measurements were obtained (geometric mean values).

\begin{tabular}{|c|c|c|c|c|}
\hline Area & Mean geom & SD geom & Min & Max \\
\hline \multicolumn{5}{|c|}{$*$ Gamma dose rate ${ }^{\mathrm{a}}, \mathrm{mSv} \mathrm{hr}^{-1}$} \\
\hline 1 & 30.4 & 1.3 & 5.7 & 59.4 \\
\hline 2 & 11.0 & 1.4 & 3.9 & 21.1 \\
\hline 3 & 1.9 & 1.3 & 0.7 & 3.4 \\
\hline \multicolumn{5}{|c|}{ *Beta flux ${ }^{\mathrm{a}}$, counts $\mathrm{min}^{-1} \mathrm{~cm}^{-2}$} \\
\hline 1 & 2385.0 & 1.5 & 956 & 9878 \\
\hline 2 & 465.1 & 1.8 & 143 & 2446 \\
\hline 3 & 125.2 & 1.4 & 56 & 277 \\
\hline \multicolumn{5}{|c|}{${ }^{90} \mathrm{Sr}$ in the soil, $\mathrm{MBq} \mathrm{m^{-2 }}$} \\
\hline 1 & 18.19 & 2.26 & 3.98 & 86.79 \\
\hline 2 & 5.02 & 2.57 & 0.44 & 14.44 \\
\hline 3 & 0.96 & 1.52 & 0.46 & 2.40 \\
\hline \multicolumn{5}{|c|}{${ }^{137} \mathrm{Cs}$ in the soil, $\mathrm{MBq} \mathrm{m}^{-2}$} \\
\hline 1 & 39.38 & 1.58 & 13.87 & 109.51 \\
\hline 2 & 14.59 & 1.82 & 5.05 & 40.30 \\
\hline 3 & 3.33 & 1.55 & 0.92 & 8.62 \\
\hline
\end{tabular}

\footnotetext{
${ }^{\mathrm{a}} 5 \mathrm{~cm}$ above the soil surface level.
} 
Table 7. Average geometric means for the ${ }^{90} \mathrm{Sr}$ and ${ }^{137} \mathrm{Cs}$ concentrations in whole bodies of small mammals of the ChEZ, Bq g ${ }^{-1}$ (live mass).

\begin{tabular}{|c|c|c|c|c|c|}
\hline \multirow{2}{*}{ Species } & \multicolumn{2}{|c|}{${ }^{90} \mathrm{Sr}$} & \multicolumn{2}{|c|}{${ }^{137} \mathrm{Cs}$} & \multirow{2}{*}{$\mathbf{N}$} \\
\hline & Mean geom. & SD geom & Mean geom & SD geom & \\
\hline \multicolumn{6}{|c|}{ Area 1} \\
\hline Bank voles & 89.5 & 2.6 & 2352.2 & 1.8 & 40 \\
\hline Wood mice & 71.3 & 1.8 & 145.5 & 1.5 & 6 \\
\hline Short tailed voles & 98.1 & 2.2 & 564.0 & 1.7 & 64 \\
\hline Common shrews & 71.7 & 2.6 & 283.8 & 1.8 & 65 \\
\hline \multicolumn{6}{|c|}{ Area 2} \\
\hline Bank voles & 19.8 & 2.1 & 50.3 & 2.0 & 263 \\
\hline Wood mice & 25.2 & 1.7 & 52.6 & 2.2 & 31 \\
\hline Common shrews & 18.1 & 2.4 & 22.3 & 1.6 & 32 \\
\hline \multicolumn{6}{|c|}{ Area 3} \\
\hline Bank voles & 5.0 & 2.8 & 3.2 & 2.1 & 31 \\
\hline Wood mice & 6.5 & 2.2 & 2.4 & 2.0 & 98 \\
\hline Short tailed voles & 7.6 & 1.6 & 3.3 & 2.4 & 17 \\
\hline Common shrews & 10.9 & 1.7 & 3.1 & 1.6 & 5 \\
\hline
\end{tabular}


Table 8. Characteristics of the beta-emitting radionuclides.

\begin{tabular}{cccc}
\hline Radionuclide & $\begin{array}{c}\text { Maximum energy, } \\
\mathbf{M e V}\end{array}$ & $\begin{array}{c}\text { Maximum range in } \\
\text { water } \mathbf{R}, \mathbf{~ m m}\end{array}$ & $\begin{array}{c}\text { Half thickness, } \\
\mathbf{m m}\end{array}$ \\
\hline${ }^{90} \mathrm{Y}$ & 2.27 & 10 & 1.0 \\
${ }^{137} \mathrm{Cs}^{\mathrm{a}}$ & 0.52 & $1.5-1.8$ & 0.17 \\
${ }^{90} \mathrm{Sr}$ & 0.34 & 0.7 & 0.1 \\
\hline
\end{tabular}

${ }^{\mathrm{a}}$ For ${ }^{137} \mathrm{Cs}$, the baseline with $92 \%$ photon yield is shown. 
Table 9. Absorbed doses and contributions of external and internal radiation into the absorbed doses for murine rodents and shrews in three different soil areas of the ChEZ in 2005.

\begin{tabular}{|c|c|c|c|c|c|c|c|}
\hline \multirow[b]{2}{*}{ Species } & \multirow{2}{*}{$\begin{array}{c}\text { Absorbed } \\
\text { dose in a } \\
24 \text { hour } \\
\text { period, } \\
\text { mGy }\end{array}$} & \multicolumn{4}{|c|}{ Contribution into the absorbed dose, $\%$} & \multirow[b]{2}{*}{$\begin{array}{c}\text { Total } \\
\text { external, } \\
\%\end{array}$} & \multirow[b]{2}{*}{$\begin{array}{c}\text { Total } \\
\text { internal, } \\
\%\end{array}$} \\
\hline & & $\begin{array}{c}\text { External } \\
\gamma\end{array}$ & $\begin{array}{c}\text { External } \\
\beta\end{array}$ & $\begin{array}{c}\text { Internal } \\
{ }^{137} \mathrm{Cs}\end{array}$ & $\begin{array}{c}\text { Internal } \\
{ }^{90} \mathrm{Sr}\end{array}$ & & \\
\hline \multicolumn{8}{|c|}{ Area 1 (peat bog soils) } \\
\hline Bank voles & 9.03 & 5.2 & 6.0 & 79.2 & 9.6 & 11.2 & 88.8 \\
\hline Wood mice & 2.19 & 22.5 & 25.8 & 20.2 & 31.5 & 48.3 & 51.7 \\
\hline Short tailed voles & 3.86 & 14.2 & 16.8 & 44.4 & 24.6 & 31.0 & 69.0 \\
\hline Common shrews & 2.89 & 20.8 & 25.3 & 29.8 & 24.0 & 46.1 & 53.9 \\
\hline \multicolumn{8}{|c|}{ Area 2 (low podzolic soils with some clay and sandy soils) } \\
\hline Bank voles & 0.62 & 27.6 & 16.9 & 24.6 & 30.9 & 44.5 & 55.5 \\
\hline Wood mice & 0.69 & 25.7 & 15.9 & 23.1 & 35.3 & 41.6 & 58.4 \\
\hline Common shrews & 0.60 & 36.0 & 23.7 & 11.3 & 29.0 & 59.7 & 40.3 \\
\hline \multicolumn{8}{|c|}{$\begin{array}{l}\text { Area } 3 \text { (dry low podzplic gleic sandy loam soils) } \\
\text { (dric }\end{array}$} \\
\hline Bank voles & 0.12 & 25.3 & 24.3 & 8.5 & 42.0 & 49.5 & 50.5 \\
\hline Wood mice & 0.13 & 23.3 & 22.7 & 5.7 & 48.2 & 46.1 & 53.9 \\
\hline Short tailed voles & 0.15 & 22.4 & 22.5 & 6.7 & 48.4 & 44.9 & 55.1 \\
\hline Common shrews & 0.19 & 19.5 & 20.2 & 5.0 & 55.4 & 39.7 & 60.3 \\
\hline
\end{tabular}


Table 10. Absorbed dose assessments compared to the Beresford et al. (2008) data, $\mu \mathrm{Gy} \mathrm{h}^{-1}$.

\begin{tabular}{|c|c|c|c|c|c|c|}
\hline \multirow{2}{*}{ Species } & \multicolumn{3}{|c|}{$\begin{array}{l}\text { Absorbed dose from the external } \\
\text { radiation }\end{array}$} & \multicolumn{3}{|c|}{ Total absorbed dose } \\
\hline & $\begin{array}{l}\text { This } \\
\text { study }\end{array}$ & TLD & $\begin{array}{c}\text { ERICA } \\
\text { Tool }\end{array}$ & This study & $\begin{array}{l}\text { ERICA Tool } \\
\text { (Tier 2) }\end{array}$ & $\begin{array}{l}\text { ERICA Tool } \\
\text { (Tier 3) }\end{array}$ \\
\hline \multicolumn{7}{|c|}{ Area 1} \\
\hline Bank voles & 42.2 & 66.5 & 20.7 & 376.4 & 1270.0 & 808.0 \\
\hline Short tailed voles & 49.8 & 43.7 & 20.7 & 161.0 & 551.0 & 277.0 \\
\hline Wood mice & 44.1 & 43.2 & 17.6 & 91.3 & 254.0 & 125.0 \\
\hline \multicolumn{7}{|c|}{ Area 2} \\
\hline Bank voles & 11.5 & 13.1 & 9.2 & 25.9 & 101.0 & 54.6 \\
\hline Wood mice & 12.0 & 17.2 & 7.8 & 28.9 & 101.0 & 52.1 \\
\hline \multicolumn{7}{|c|}{ Area 3} \\
\hline Bank voles & 2.4 & 2.1 & 1.8 & 4.8 & 22.0 & 12.2 \\
\hline Wood mice & 2.5 & 1.5 & 1.5 & 5.4 & 20.3 & 12.9 \\
\hline
\end{tabular}

